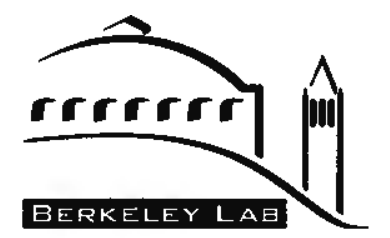

ENVIRONMENT, HEALTH \& BAFETY DIVIBION

June 4, 2011

DIR-12-012

Ms. Aundra Richards

Department of Energy

Berkeley Site Office

Berkeley Laboratory

1 Cyclotron Road, MS 90R1042

Berkeley, CA 94720

Subject: Radionuclide Air Emission Report for 2011

Dear Ms. Richards:

I'm pleased to present, for DOE Site Office certification, Berkeley Lab's Radionuclide Air Emission Report for 2011, as required by Subpart H of 40 CFR Part 61 of the National Emission Standards for Hazardous Air Pollutants (NESHAP). Please note that the calculated dose of 0.005 mrem $(0.000073$ $\mathrm{mSv}$ ) from Berkeley Lab airborne emissions in 2011 is well below the Environmental Protection Agency (EPA) dose standard of $10 \mathrm{mrem} /$ year $(0.1 \mathrm{mSv} /$ year $)$.

The report is due to EPA by June 30,2011. After signing the certification statement (located on page 17), please send the report to Ms. Deborah Jordan, EPA Region 9. Please forward a copy of the certification page to Ron Pauer (MS 75R0123). If you have any questions on this report, please contact Ron at (510) 486-7614.

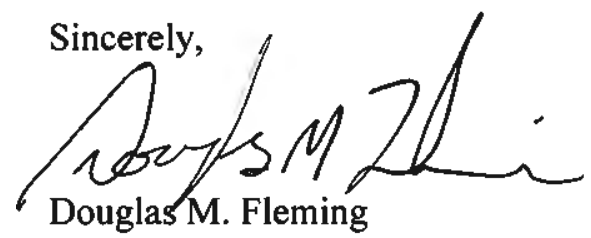

EHS Division Director, Lawrence Berkeley National Laboratory

DMF:lw

Attachment

cc: w/ Attachment

w/o Attachment

K. Abbott (DOE)

D. Kestell

J. Krupnick

R. Pauer

N. Ware

L. Wahl 


\title{
Radionuclide Air Emission Report for 2011
}

\author{
Prepared by: \\ Environment, Health and Safety Division \\ Environmental Services Group
}

June 4, 2012

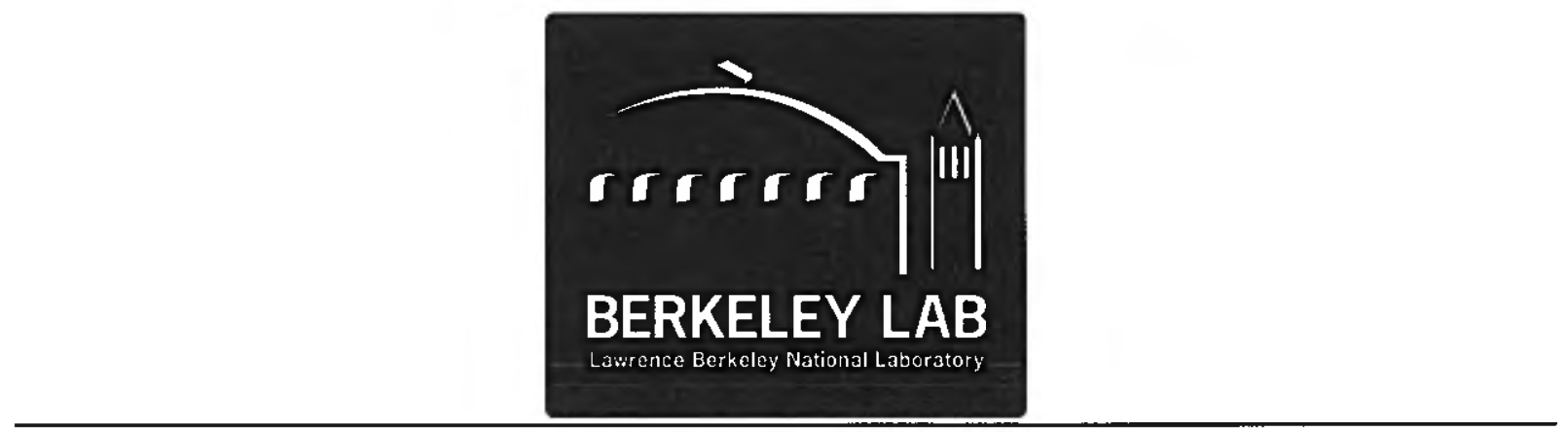

Emest Orlando Lawrence Berkeley National Laboratory

Berkeley, CA 94720

This work was supported by the Director, Office of Science, U.S. Department of Energy under Contract No. DE-AC02-05CH11231. 



\section{U.S. Department of Energy \\ Radionuclide Air Emission Report for 2011 \\ (in compliance with 40 CFR 61, Subpart H)}

Site Name: $\quad$ Ernest Orlando Lawrence Berkeley National Laboratory

Operation Office Information

Office: $\quad$ U.S. Department of Energy

Berkeley Site Office

Address: $\quad$ MS 90R1023

One Cyclotron Road

Berkeley, CA 94720

Contact: $\quad$ Kim Abbott $\quad$ Phone:(510) 486-7909

Site Information

Operator: University of California

Address: $\quad$ MS 75R0123

One Cyclotron Road

Berkeley, CA 94720

Contact: $\quad$ Linnea Wahl, CHP Phone:(510) 486-7623 


\section{Table of Contents}

Preface

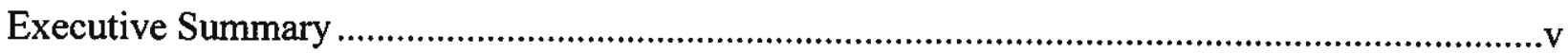

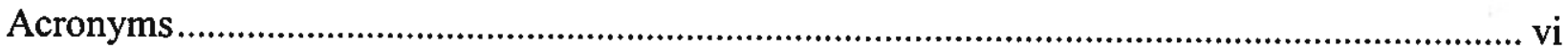

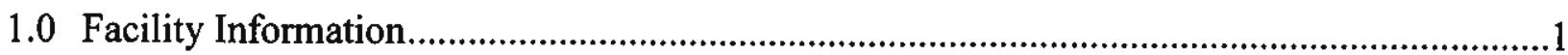

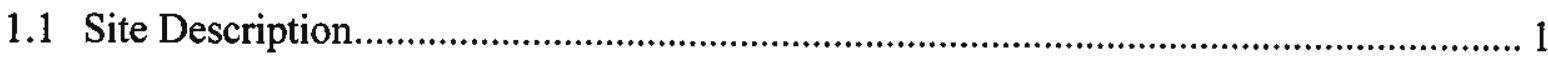

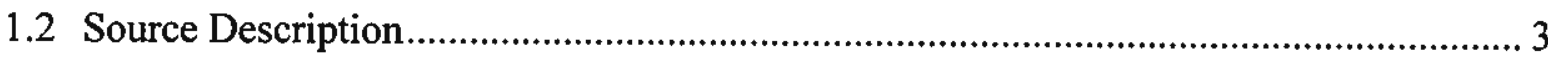

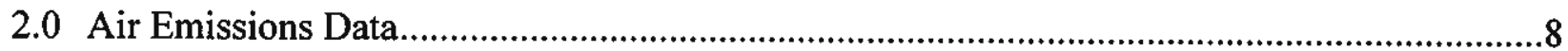

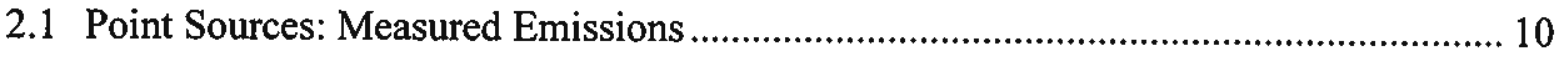

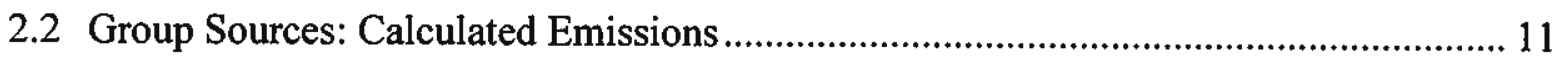

2.3 Nonpoint Sources: Diffuse Emissions ...................................................................... 12

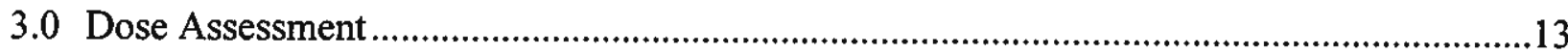

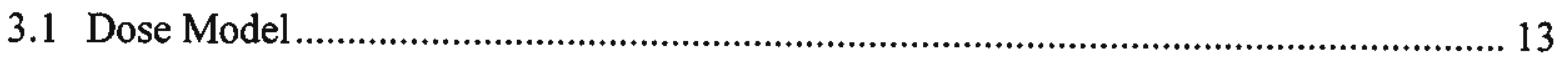

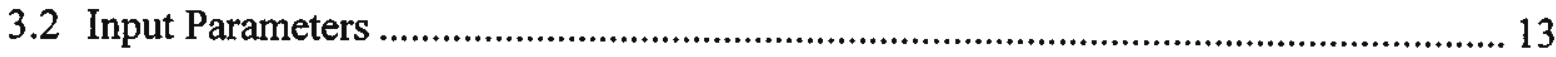

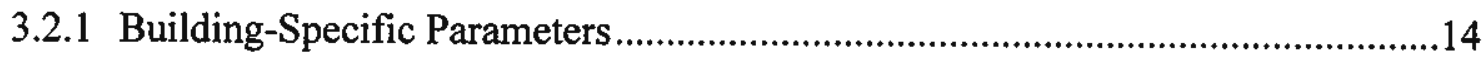

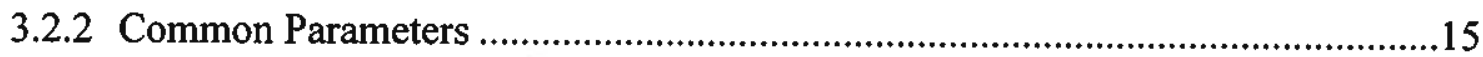

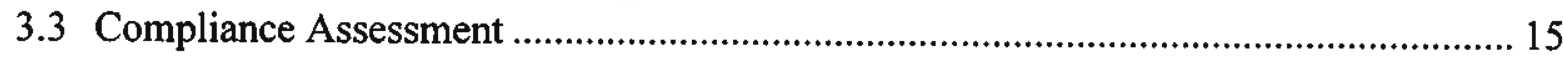

3.3.1 MEI Dose and Location ..............................................................................15

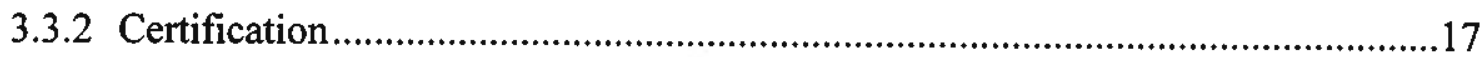

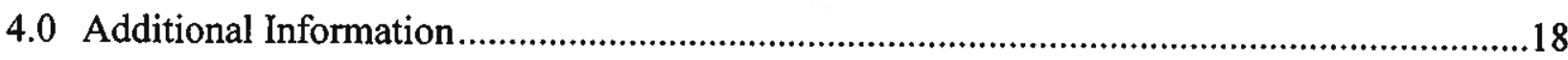

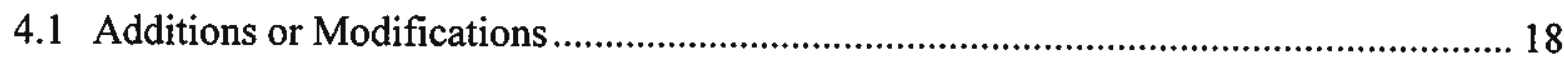

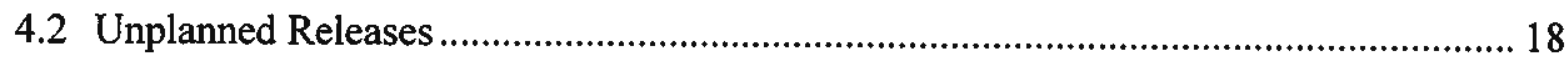

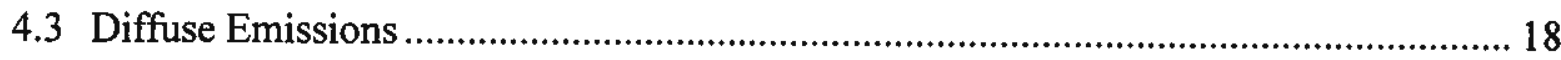

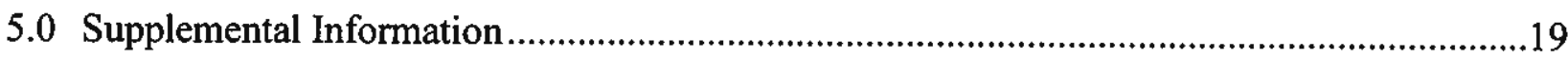

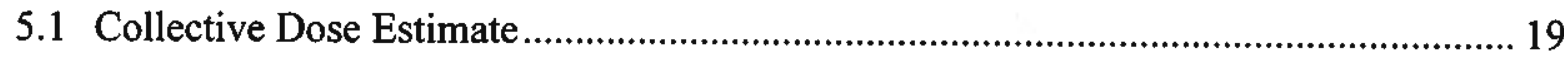

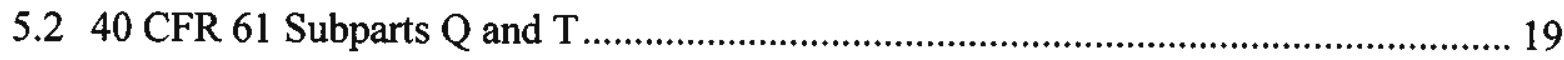

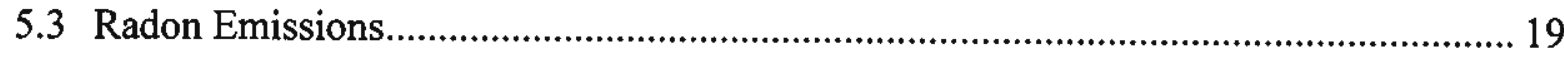

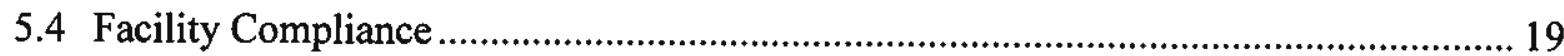

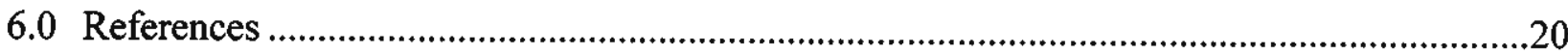

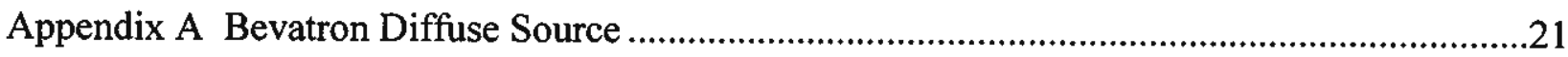

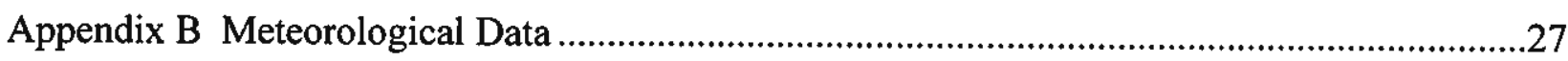

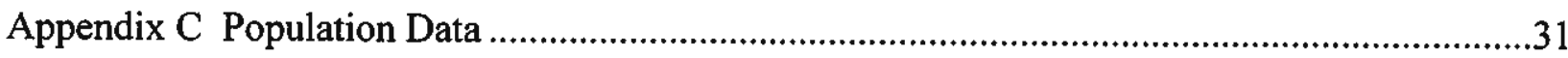




\section{LIST OF TABLES}

Table 1-1 Buildings Where Unsealed Radionuclide Use or Production is Authorized by Berkeley Lab...............................................................................................

Table 2-1 EPA-Approved Radionuclide Emissions Measurement Approach ................................ 8

Table 2-2 Measurement Category of Sources ........................................................................... 9

Table 2-3 Total Activity Emitted in 2011 ............................................................................... 10

Table 2-4 Stacks Where Radionuclide Emissions are Measured ................................................... 11

Table 2-5 Sources for Which Radionuclide Emissions are Calculated........................................ 12

Table 3-1 Building-Specific Input Parameters..................................................................... 14

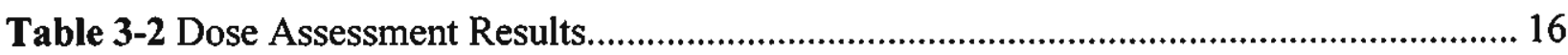

\section{LIST OF FIGURES}

Figure 1-1 San Francisco Bay Area Map...................................................................... 2

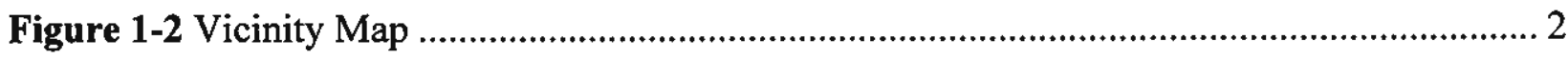

Figure 1-3 Berkeley Lab Buildings Where Radionuclides are Used or Produced.......................... 4 
As a U.S. Department of Energy (DOE) facility whose operations involve the use of radionuclides, Berkeley Lab is subject to U.S. Environmental Protection Agency (EPA) radioactive air emission regulations in Code of Federal Regulations (CFR) Title 40, Part 61, National Emission Standards for Hazardous Air Pollutants (NESHAP) (EPA 1989a). Subpart H of this regulation (subsequently referred to as NESHAP) establishes standards for exposure of the public to radionuclides (other than radon) released from DOE facilities. This regulation limits the emission of radionuclides to ambient air from DOE facilities. Such emissions may not exceed amounts that would cause any member of the public to receive an effective dose equivalent (subsequently referred to as dose) of $10 \mathrm{mrem} / \mathrm{yr}(0.1 \mathrm{mSv} / \mathrm{yr})$.

Under the NESHAP regulation, DOE facilities are required to submit an annual report each year. The NESHAP regulation specifies the content of the report and DOE provides further guidance (DOE 1994). This document is Berkeley Lab's annual report on radionuclide air emissions and meets the NESHAP requirements for reporting. This report can be found on the Laboratory's website at http//www.lbl.gov/ehs/esg/Reports/tableforreports.shtml. 


\section{Executive Summary}

Berkeley Lab operates facilities where radionuclides are produced, handled, stored, and potentially emitted. These facilities are subject to the EPA radioactive air emission regulations in 40 CFR 61, Subpart H (EPA 1989a). Radionuclides may be emitted from stacks or vents on buildings where radionuclide production or use is authorized or they may be emitted as diffuse sources. In 2011, all Berkeley Lab sources were minor sources of radionuclides (sources resulting in a potential dose of less than $0.1 \mathrm{mrem} / \mathrm{yr}[0.001 \mathrm{mSv} / \mathrm{yr}]$ ). These minor sources included about 90 stack sources and one source of diffuse emissions. There were no unplanned airborne radionuclide emissions from Berkeley Lab operations. Emissions from minor sources (stacks and diffuse emissions) were measured by sampling or monitoring or were calculated based on quantities used, received for use, or produced during the year. Using measured and calculated emissions, and building-specific and common parameters, Laboratory personnel applied the EPA-approved computer codes, CAP88-PC and COMPLY, to calculate the effective dose equivalent to the maximally exposed individual (MEI).

The effective dose equivalent from all sources at the Berkeley Lab main site in 2011 was $5.0 \times 10^{-3}$ $\mathrm{mrem} / \mathrm{yr}\left(5.0 \times 10^{-5} \mathrm{mSv} / \mathrm{yr}\right)$ to the MEI, well below the $10 \mathrm{mrem} / \mathrm{yr}(0.1 \mathrm{mSv} / \mathrm{yr})$ dose standard. The location of this MEI is at the University of California (UC) Lawrence Hall of Science, a public science museum about $1500 \mathrm{ft}(460 \mathrm{~m})$ east of Berkeley Lab's Building 56. The estimated collective effective dose equivalent to persons living within $50 \mathrm{mi}(80 \mathrm{~km})$ of the Berkeley Lab main site was $1.1 \times 10^{-1}$ person-rem $\left(1.1 \times 10^{-3}\right.$ person-Sv) attributable to the Lab's airborne emissions in 2011 .

The effective dose equivalent from all sources at Berkeley Lab operations at the Berkeley West Biocenter (Building 977 at 717 Potter Street, Berkeley) in 2011 was $2.4 \times 10^{-4} \mathrm{mrem} / \mathrm{yr}\left(2.4 \times 10^{-6} \mathrm{mSv} / \mathrm{yr}\right)$ to the $\mathrm{MEI}$, well below the $10 \mathrm{mrem} / \mathrm{yr}(0.1 \mathrm{mSv} / \mathrm{yr})$ dose standard. The location of this MEI is in the Berkeley West Biocenter's Potter Street building, about $98 \mathrm{ft}(30 \mathrm{~m})$ from the point where emissions from Berkeley Lab operations are released. The estimated collective effective dose equivalent to persons living within 50 $\mathrm{mi}(80 \mathrm{~km})$ was $9.5 \times 10^{-6}$ person-rem $\left(9.5 \times 10^{-8}\right.$ person-Sv) attributable to the Lab's airborne emissions from Building 977 in 2011.

The effective dose equivalent from all sources at Berkeley Lab operations at the Joint BioEnergy Institute (Building 978 at 5885 Hollis Street, Emeryville) in 2011 was $4.6 \times 10^{-5} \mathrm{mrem} / \mathrm{yr}\left(4.6 \times 10^{-7} \mathrm{mSv} / \mathrm{yr}\right)$ to the MEI, well below the $10 \mathrm{mrem} / \mathrm{yr}(0.1 \mathrm{mSv} / \mathrm{yr})$ dose standard. The location of this $\mathrm{MEI}$ is in the Joint BioEnergy Institute's Hollis Street building, about $62 \mathrm{ft}(19 \mathrm{~m})$ from the point where emissions from Berkeley Lab operations are released. The estimated collective effective dose equivalent to persons living within $50 \mathrm{mi}(80 \mathrm{~km})$ was $1.7 \times 10^{-7}$ person-rem $\left(1.7 \times 10^{-9}\right.$ person-Sv) attributable to the Lab's airbome emissions from Building 978 in 2011. 


\section{Acronyms}

$\begin{array}{ll}\text { ALS } & \text { Advanced Light Source } \\ \text { CAP88-PC } & \text { EPA-approved dose calculation software } \\ \text { CFR } & \text { Code of Federal Regulations } \\ \text { COMPLY } & \text { EPA-approved dose calculation software } \\ \text { DOE } & \text { U. S. Department of Energy } \\ \text { EPA } & \text { U. S. Environmental Protection Agency } \\ \text { HEPA } & \text { High-efficiency particulate air } \\ \text { JBEI } & \text { Joint BioEnergy Institute } \\ \text { LHS } & \text { Lawrence Hall of Science } \\ \text { LOASIS } & \text { Lasers and Optical Accelerator Systems Integrated Studies } \\ \text { MEI } & \text { Maximally exposed individual } \\ \text { NESHAP } & \text { National Emission Standards for Hazardous Air Pollutants } \\ \text { TEDA } & \text { Triethylene diamine } \\ \text { TEDA-DAC } & \text { Triethylene-diamine-doped activated carbon } \\ \text { UC } & \text { University of California }\end{array}$




\section{0 \\ Facility Information}

Lawrence Berkeley National Laboratory, also known as Berkeley Lab, was founded by Ernest $\mathrm{O}$. Lawrence in 1931. Lawrence invented a unique particle accelerator, called a cyclotron, which ushered in a new era in the study of subatomic particles. In 1939, he was awarded the Nobel Prize in physics. Through his work, Lawrence launched the modern era of multidisciplinary, team science. Today, Berkeley Lab continues the tradition of multidisciplinary scientific teams working together to solve global problems in human health, technology, energy, and the environment.

The Laboratory supports work in such diverse fields as genomics, physical biosciences, alternative fuels, nanoscience, life sciences, fundamental physics, accelerator physics and engineering, energy conservation technology, and materials science. Through its fundamental research in these fields, Berkeley Lab has achieved international recognition for its leadership and has made numerous contributions to national programs. Berkeley Lab's research embraces the following concepts to align with the DOE mission:

- Explore the complexity of energy and matter

- Advance the science needed to attain abundant clean energy

- Understand energy impacts on our living planet

- Provide extraordinary tools for multidisciplinary research

\subsection{Site Description}

Berkeley Lab is located about $3 \mathrm{mi}(5 \mathrm{~km}$ ) east of San Francisco Bay (see Figure 1-1) on land owned by UC. The Laboratory's main site is situated on approximately 202 acres ( 82 hectares) of this land. University of California provides long-term land leases to the DOE for many of the buildings and facilities at the Laboratory.

The main site lies in the hills above the UC Berkeley campus, on the ridges and draws of Blackberry Canyon (which forms much of the western part of the site) and Strawberry Canyon (which forms much of the southern part of the site). Elevations across the site range from 450 to $1,150 \mathrm{ft}$ (135 to $350 \mathrm{~m}$ ) above sea level. The western portion of the site is in Berkeley, while the eastern portion is in Oakland; the entire site is located within Alameda County (see Figure 1-2). The residential population of Berkeley is estimated at 113,000 and that of Oakland at 391,000 (MTC/ABAG 2010).

Berkeley Lab also leases space at two nearby, off-site buildings where radionuclides are used in biological research. The Berkeley West Biocenter (Building 977) is located at 717 Potter St. in Berkeley, and the Joint BioEnergy Institute (JBEI, Building 978) is located at 5885 Hollis St. in Emeryville (see Figure 1-2). Elevations at these buildings range from 35 to $50 \mathrm{ft}$ (11 to $15 \mathrm{~m}$ ) above sea level. Emeryville is a small community between Berkeley and Oakland with a residential population of 10,100 (MTC/ABAG 2010). Radionuclide use was not authorized at any other off-site locations in 2011. 


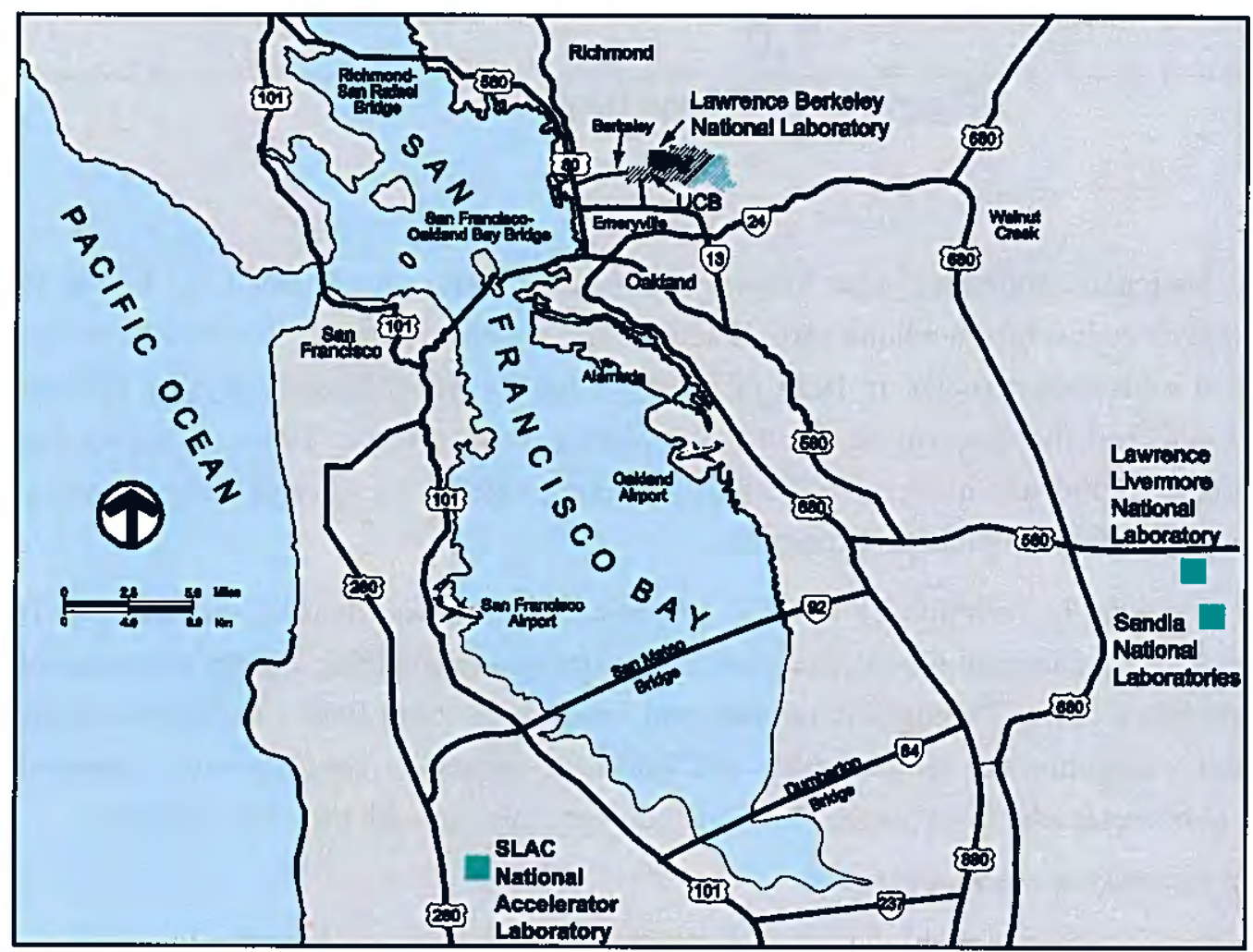

Figure 1-1 San Francisco Bay Area Map

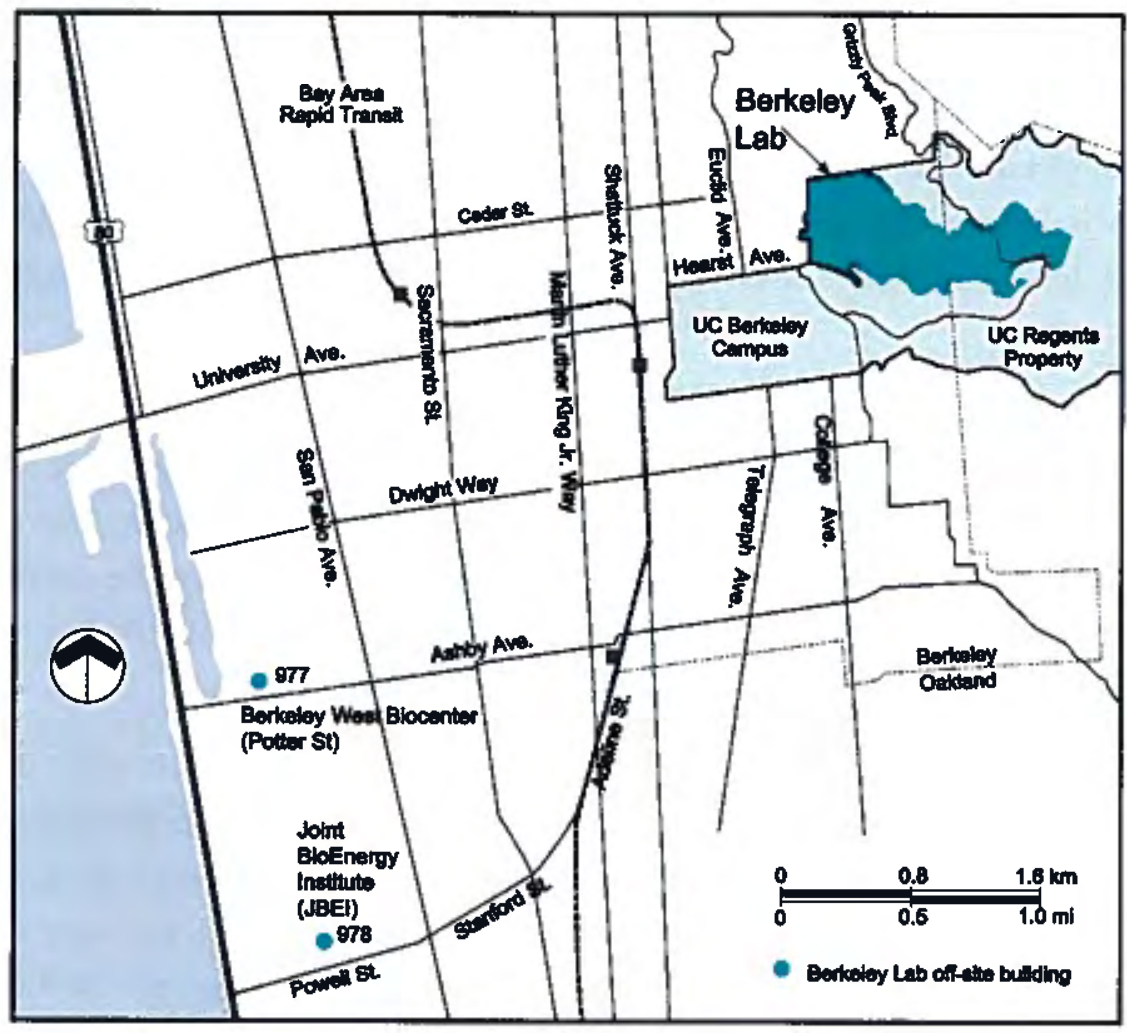

Figure 1-2 Vicinity Map 
Adjacent land use consists of residential, institutional, and recreational areas. The area to the south and east of the Laboratory main site, which is UC land, is maintained largely in a natural or undeveloped state but includes UC Berkeley's Strawberry Canyon Recreational Area and Botanical Garden. To the northeast are the university's Lawrence Hall of Science, Space Sciences Laboratory, and Mathematical Sciences Research Institute. Berkeley Lab is bordered on the north by a residential neighborhood of lowdensity, single-family homes and on the west by the UC Berkeley campus, as well as by multiunit dwellings, student residence halls, and private homes. The area to the west of Berkeley Lab is highly urbanized.

The climate of the site is temperate, influenced by the moderating effects of nearby San Francisco Bay and the Pacific Ocean to the west, and on the east by the East Bay hills paralleling the eastern shore of this same bay. These physical barriers contribute significantly to the relatively warm, wet winters and cool, dry summers of the site. In 2011 , precipitation totaled $27.3 \mathrm{in} .(69.3 \mathrm{~cm})$, absolute humidity averaged $7.5 \mathrm{~g} / \mathrm{m}^{3}$, and ambient temperature averaged $53.4^{\circ} \mathrm{F}\left(11.9^{\circ} \mathrm{C}\right)$.

On-site wind patterns change little from one year to the next. The most prevalent wind pattern occurs during fair weather, with daytime westerly winds blowing off the bay, followed by lighter nighttime southeasterly drainage winds of the East Bay hills. The other predominant wind pattern is associated with storm systems passing through the region, which usually occur during the winter months. South-tosoutheast winds in advance of each storm are followed by a shift to west or northwest winds after passage of the system.

Vegetation on the Berkeley Lab main site is a mixture of native plants, naturalized exotics, and ornamental species. The site was intensively grazed and farmed for approximately 150 years before the development of Berkeley Lab on it in the 1930s. At the main site, the Laboratory manages vegetation in harmony with the local natural succession of native plant communities. Berkeley Lab also works to maintain a wooded and savanna character in the areas surrounding buildings and roads. Ornamental species are generally restricted to public spaces and courtyards and to areas adjacent to buildings. The site has no rare, threatened, or endangered species of plants.

Wildlife is abundant at the Berkeley Lab main site because the site is adjacent to open spaces managed by the East Bay Regional Park District and the university. Wildlife that frequents the site is typical of wildlife in disturbed (for example, previously grazed) areas that have a Mediterranean climate and are located in midlatitude California. More than 120 species of birds, mammals, reptiles, and amphibians are thought to exist on the site. The most abundant large mammal is the Colombian black-tailed deer. The Berkeley Lab main site includes protected habitats for riparians, a certain spider species, and a threatened snake species.

\subsection{Source Description}

Berkeley Lab operates facilities subject to the EPA's NESHAP regulations where radionuclides are produced, handled, stored, and potentially emitted (EPA 1989a). Figure 1-3 illustrates the Berkeley Lab general site configuration, including locations of buildings where radionuclides are used or produced and 


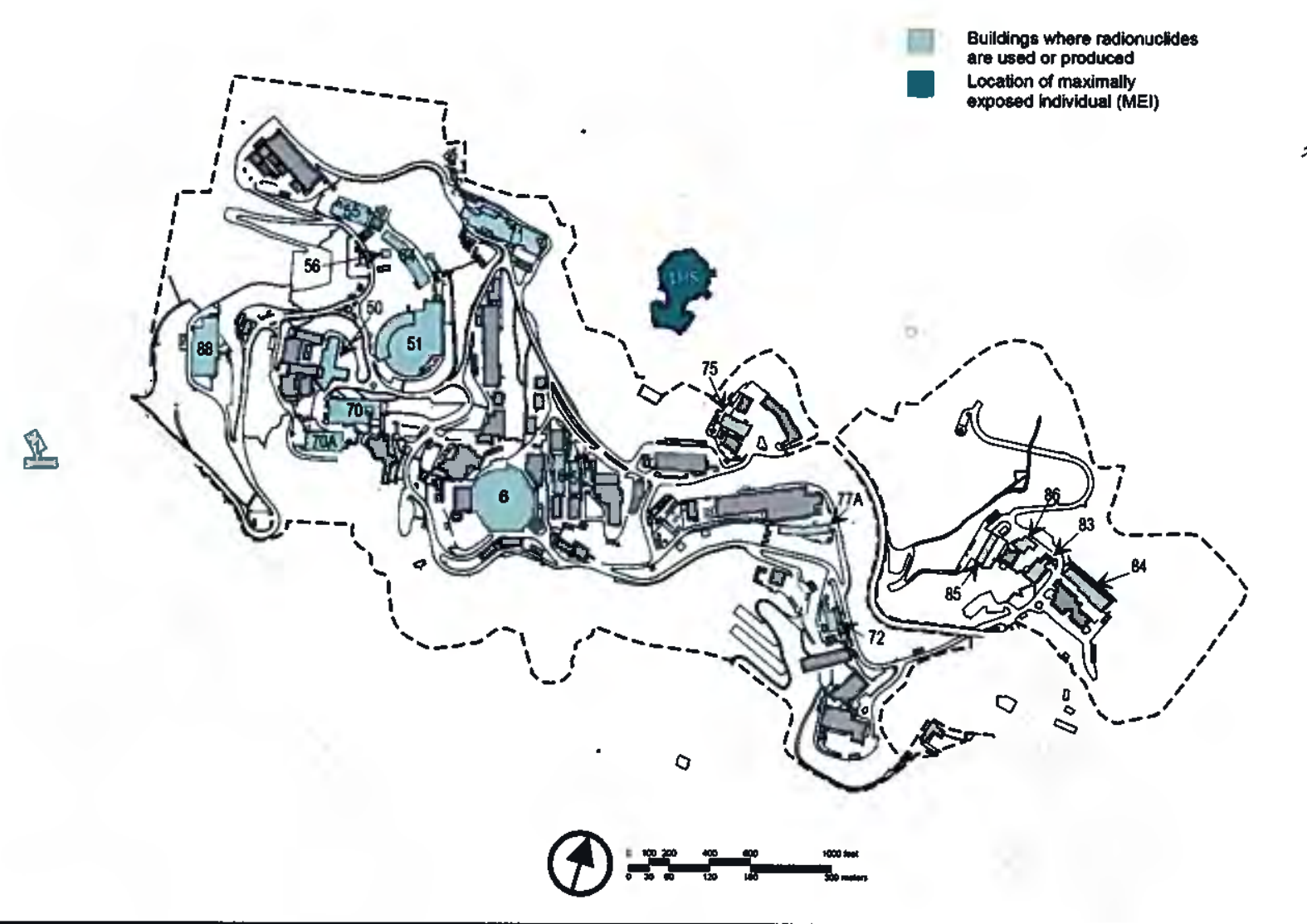

Figure 1-3 Berkeley Lab Buildings Where Radionuclides are Used or Produced

the Lawrence Hall of Science (LHS), the location of the MEI. Radionuclides are also used at two off- site locations: Building 977 (the Berkeley West Biocenter) and Building 978 (the Joint BioEnergy Institute). These two locations are shown on Figure 1-2.

Researchers at the Lab use a wide variety of radionuclides in gas, liquid, and solid phases in their research programs. Work with radioactive material may be conducted on laboratory bench tops, in fumehoods, in gloveboxes, and/or under ultra-high vacuum. In addition, radioactive gases are a by-product of chargedparticle accelerator operations in Buildings $6,56,71$, and 88 include ${ }^{41} \mathrm{Ar},{ }^{7} \mathrm{Be},{ }^{11} \mathrm{C},{ }^{13} \mathrm{~N},{ }^{15} \mathrm{O},{ }^{18} \mathrm{~F},{ }^{38} \mathrm{Cl}$, and ${ }^{39} \mathrm{Cl}$, all of which are short-lived radionuclides.

Radiochemical and radiobiological studies performed at Berkeley Lab typically use microcurie to tens of millicurie quantities of a variety of radionuclides. All use of radioactive material is conducted in accordance with a Berkeley Lab authorization or permit. An authorization or permit establishes the location of radioactive material areas (work areas where unsealed radioactive material is handled) and radioactive material storage areas (controlled areas where radioactive material is stored only, with no direct manipulation of the material), the required handling procedures, and appropriate work enclosures for each project. 
Table 1-1 identifies buildings at Berkeley Lab where use or production of unsealed radioactive material was authorized in 2011 and the radionuclides that were produced or authorized for use. Note that not all authorized radionuclides were used during the year. 


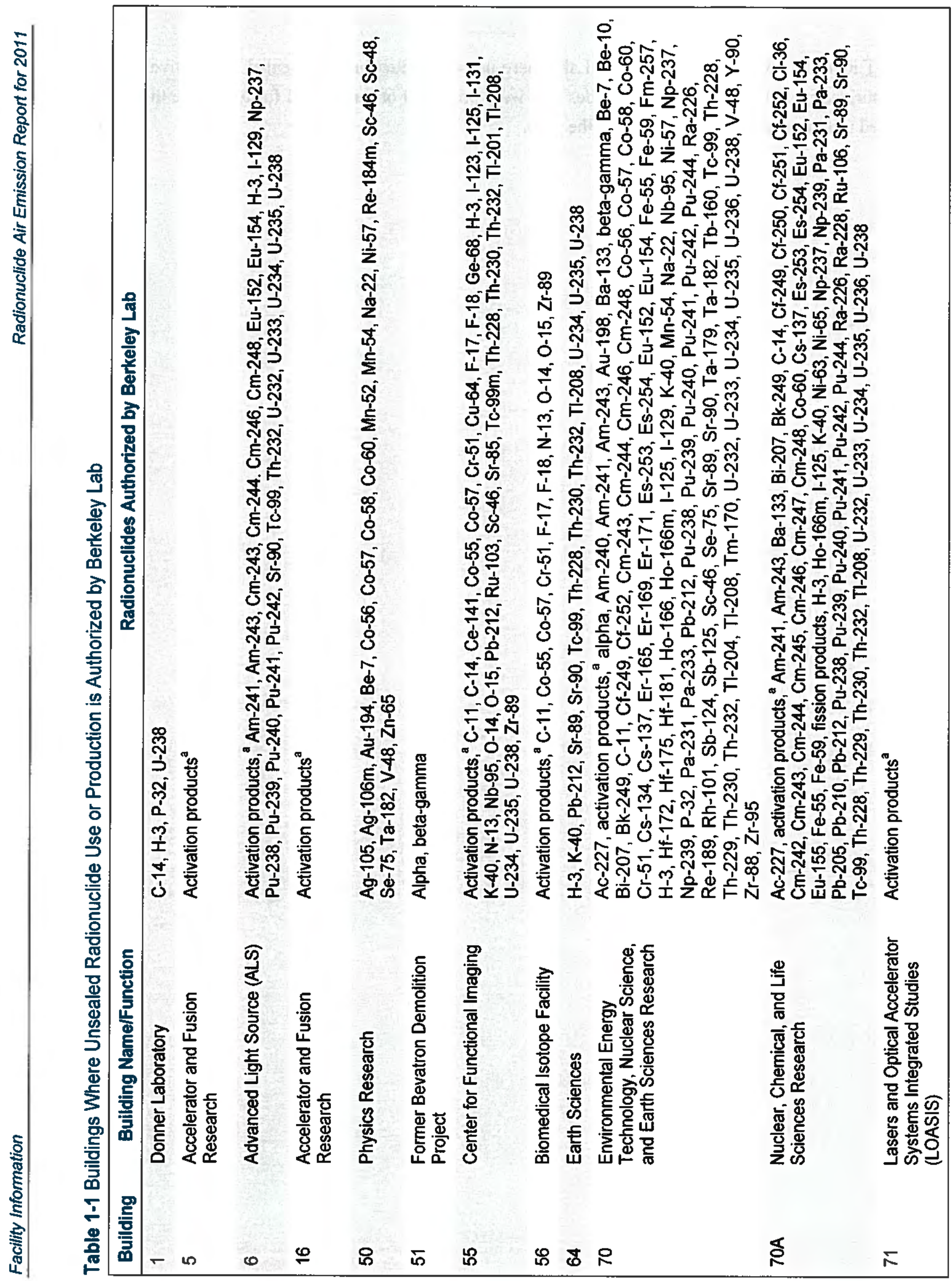




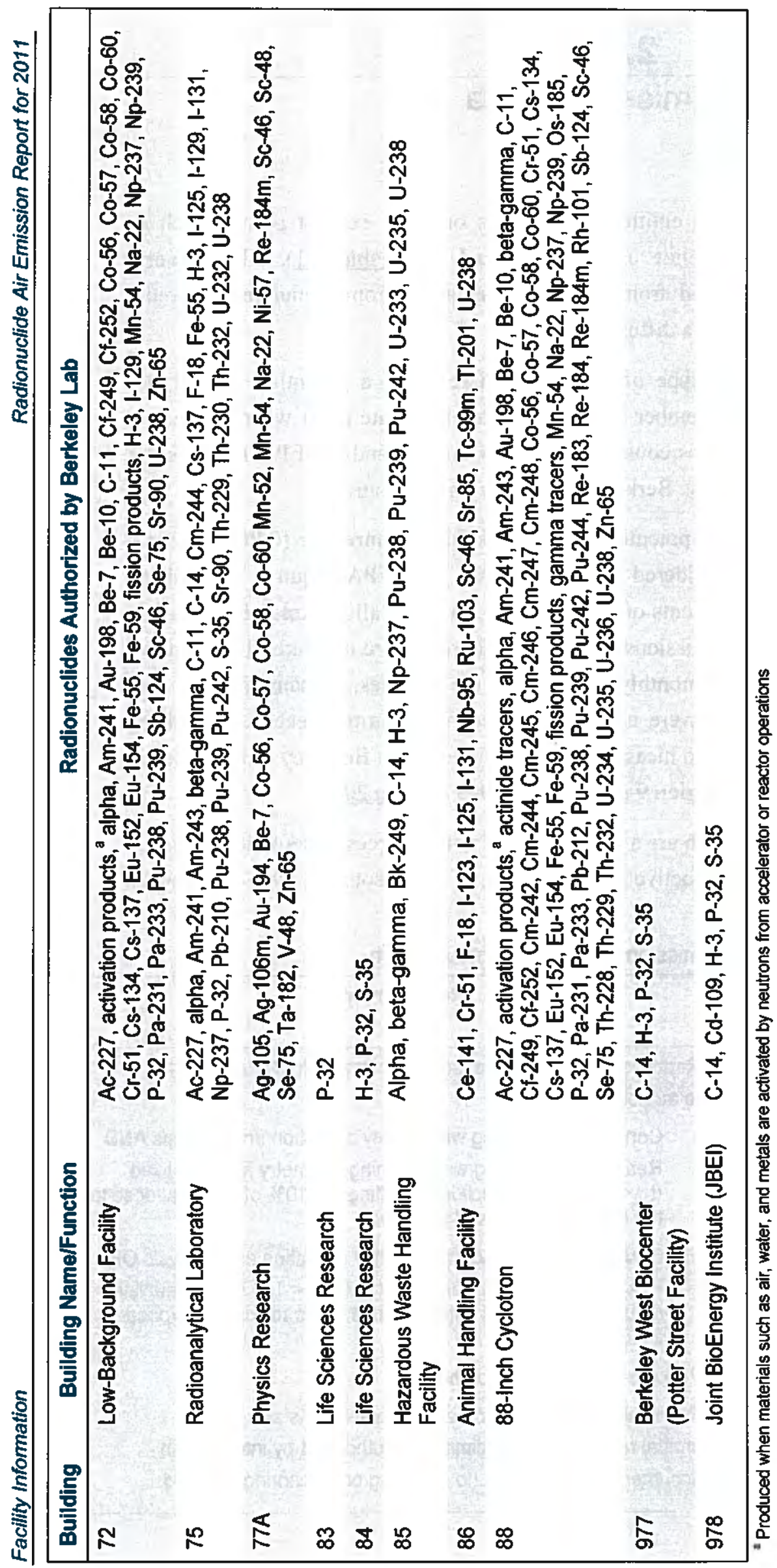




\section{Air Emissions Data}

At Berkeley Lab, radionuclides may be emitted from stacks or other exhaust points (such as vents) on the buildings where radionuclide use is authorized (see Table 1-1). Alternatively, radionuclides may be uniformly released from an area or emanate from a number of points randomly distributed over an area; this is a diffuse source.

If the radionuclides emitted from any type of source could result in a potential dose of 0.1 $\mathrm{mrem} / \mathrm{yr}(0.001 \mathrm{mSv} / \mathrm{yr})$ or more to a member of the public at an off-site point where there is a residence, school, business, or office, it is considered a major source, and the EPA requires the Lab to measure its emissions continuously. Berkeley Lab has no major sources.

If emitted radionuclides could result in a potential dose of less than $0.1 \mathrm{mrem} / \mathrm{yr}(0.001 \mathrm{mSv} / \mathrm{yr})$, the source of the radionuclides is considered a minor source. The EPA requires the Lab to perform periodic confirmatory measurements on such sources. In 2011, all Berkeley Lab sources were minor sources of radionuclides. Emissions from minor sources were measured by real-time monitoring, continuous sampling with monthly analysis of the samples, or sampling for one month at a time four times a year; or were calculated based on quantities received, used, or produced during the year. The approach to measuring radionuclides from Berkeley Lab sources is summarized in Table 2-1, which EPA Region 9 approved in 2005 (Jordan 2005).

Among the minor sources at Berkeley Lab are a few stacks, or point sources, where the emissions are measured. There are many more radioactive material areas, or group sources, where emissions are calculated.

Table 2-1 EPA-Approved Radionuclide Emissions Measurement Approach

\begin{tabular}{|c|c|c|}
\hline $\begin{array}{l}\text { Potential Dose } \\
(\text { mrem/yr) }\end{array}$ & Category & Requirements \\
\hline dose $\geq 10.0$ & Non-compliant & $\begin{array}{l}\text { Reduction or relocation of source term and reevaluation prior } \\
\text { to authorization. }\end{array}$ \\
\hline $10.0>$ dose $\geq 1.0$ & 1 & $\begin{array}{l}\text { - Continuous sampling with weekly collection and analysis AND } \\
\text { - Real-time monitoring with alarming telemetry for short-lived } \\
\text { ( } \mathrm{t}_{1 / 2}<100 \mathrm{~h} \text { ) radionuclides resulting in }>10 \% \text { of potential dose to } \\
\text { the maximally exposed individual. }\end{array}$ \\
\hline $1.0>$ dose $\geq 0.1$ & 2 & $\begin{array}{l}\text { - Continuous sampling with monthly collection and analysis OR } \\
\text { - Real-time monitoring for short-lived }\left(\mathrm{t}_{12}<100 \mathrm{~h}\right) \text { radionuclides } \\
\text { resulting in }>10 \% \text { of potential dose to the maximally exposed } \\
\text { individual. }\end{array}$ \\
\hline $0.1>$ dose $\geq 0.01$ & 3 & Periodic sampling $25 \%$ of the year. \\
\hline dose $<0.01$ & 4 & $\begin{array}{l}\text { Potential dose evaluation before project starts and when } \\
\text { annual radionuclide use limits (as authorized by internal Lab } \\
\text { documents) are revised; no sampling or monitoring required. }\end{array}$ \\
\hline
\end{tabular}

$1 \mathrm{mrem}=0.01 \mathrm{mSv}$ 
Occasionally, activities at the Laboratory result in a diffuse source of radionuclide emissions. Diffuse sources are not actively ventilated and their emissions may be measured or calculated, depending on potential dose from those emissions (Table 2-1). In 2011, Berkeley Lab had one potential minor diffuse source, created during demolition of the former Bevatron, Building 51, which required breaking up concrete that had been part of the Bevatron accelerator structure and moving soil that had been under the accelerator. Although emissions were controlled by spraying water whenever there was visible dust, concrete and soil handling could result in diffuse airborne emissions. Because the concrete and soil came from an accelerator facility, very low levels of radionuclides have been measured in these materials.

A single building may have all three types of sources: point (measured stacks [typically Category 3]), group (calculated emissions [Category 4]), and diffuse (calculated wide-area emissions [Category 3 or 4]) sources. A tabulation of the different types of Berkeley Lab sources is provided in Table 2-2.

Table 2-2 Measurement Category of Sources

\begin{tabular}{|c|c|c|c|c|c|}
\hline \multirow[b]{2}{*}{ Building } & \multicolumn{2}{|c|}{ Major Sources } & \multicolumn{2}{|c|}{ Minor Sources } & \multirow[b]{2}{*}{ Total } \\
\hline & Category 1 & Category 2 & Category 3 & Category 4 & \\
\hline 1 & 0 & 0 & 0 & 5 & 5 \\
\hline 5 & 0 & 0 & 0 & 1 & 1 \\
\hline 6 & 0 & 0 & 0 & 2 & 2 \\
\hline 16 & 0 & 0 & 0 & 1 & 1 \\
\hline 50 & 0 & 0 & 0 & 2 & 2 \\
\hline 51 & 0 & 0 & 0 & 1 (diffuse) & 1 \\
\hline 55 & 0 & 0 & 0 & 10 & 10 \\
\hline 56 & 0 & 0 & 2 & 0 & 2 \\
\hline 64 & 0 & 0 & 0 & 1 & 1 \\
\hline 70 & 0 & 0 & 0 & 12 & 12 \\
\hline $70 \mathrm{~A}$ & 0 & 0 & 2 & 24 & 26 \\
\hline 71 & 0 & 0 & 0 & 1 & 1 \\
\hline 72 & 0 & 0 & 0 & 1 & 1 \\
\hline 75 & 0 & 0 & 1 & 3 & 4 \\
\hline $77 \mathrm{~A}$ & 0 & 0 & 0 & 1 & 1 \\
\hline 83 & 0 & 0 & 0 & 2 & 2 \\
\hline 84 & 0 & 0 & 0 & 4 & 4 \\
\hline 85 & 0 & 0 & 2 & 0 & 2 \\
\hline 86 & 0 & 0 & 0 & 1 & 1 \\
\hline 88 & 0 & 0 & 3 & 1 & 4 \\
\hline 977 & 0 & 0 & 0 & 4 & 4 \\
\hline 978 & 0 & 0 & 0 & 3 & 3 \\
\hline Total & 0 & 0 & 10 & 80 & 90 \\
\hline
\end{tabular}


The point, group, and diffuse sources at Berkeley Lab comprise many different radionuclides that were authorized for use in 2011 (see Table 1-1); however, not all of those radionuclides were actually received, used, or produced (and thus potentially emitted into the air) during the year. Radionuclides that could have been emitted during the year are listed in Table 2-3, along with the total activity of each radionuclide from stack air measurements and calculations.

\subsection{Point Sources: Measured Emissions}

In accordance with the EPA-approved approach (Table 2-1), Berkeley Lab measures emissions from stacks or other exhaust points if the potential dose from the sources could exceed 0.01 $\mathrm{mrem} / \mathrm{yr}(0.0001 \mathrm{mSv} / \mathrm{yr}$ ); these are Category 3 sources (recall that Berkeley Lab has no major [Category 1 or 2] sources). Additionally, Berkeley Lab may choose to measure emissions from stacks with less dose impact (Category 4) to ensure that those emissions are well understood. Thus stacks where emissions are measured include both Category 3 and Category 4 sources (Table 2-4).

At sampled stacks, a representative sample of the exhaust air passes through the appropriate collection medium (silica gel for ${ }^{3} \mathrm{H}$, sodium hydroxide solution for ${ }^{14} \mathrm{C}$, activated carbon for ${ }^{125} \mathrm{I}$, and fiberglass filter for particulate alpha- and beta-emitting radionuclides). Each medium is changed out after a month, and the radionuclides collected on the media are analyzed at a commercial laboratory. At sites that are continuously monitored in real time, a sample of the exhaust air is passed through or over detectors that provide a nearly instantaneous measurement

Table 2-3 Total Activity Emitted in 2011

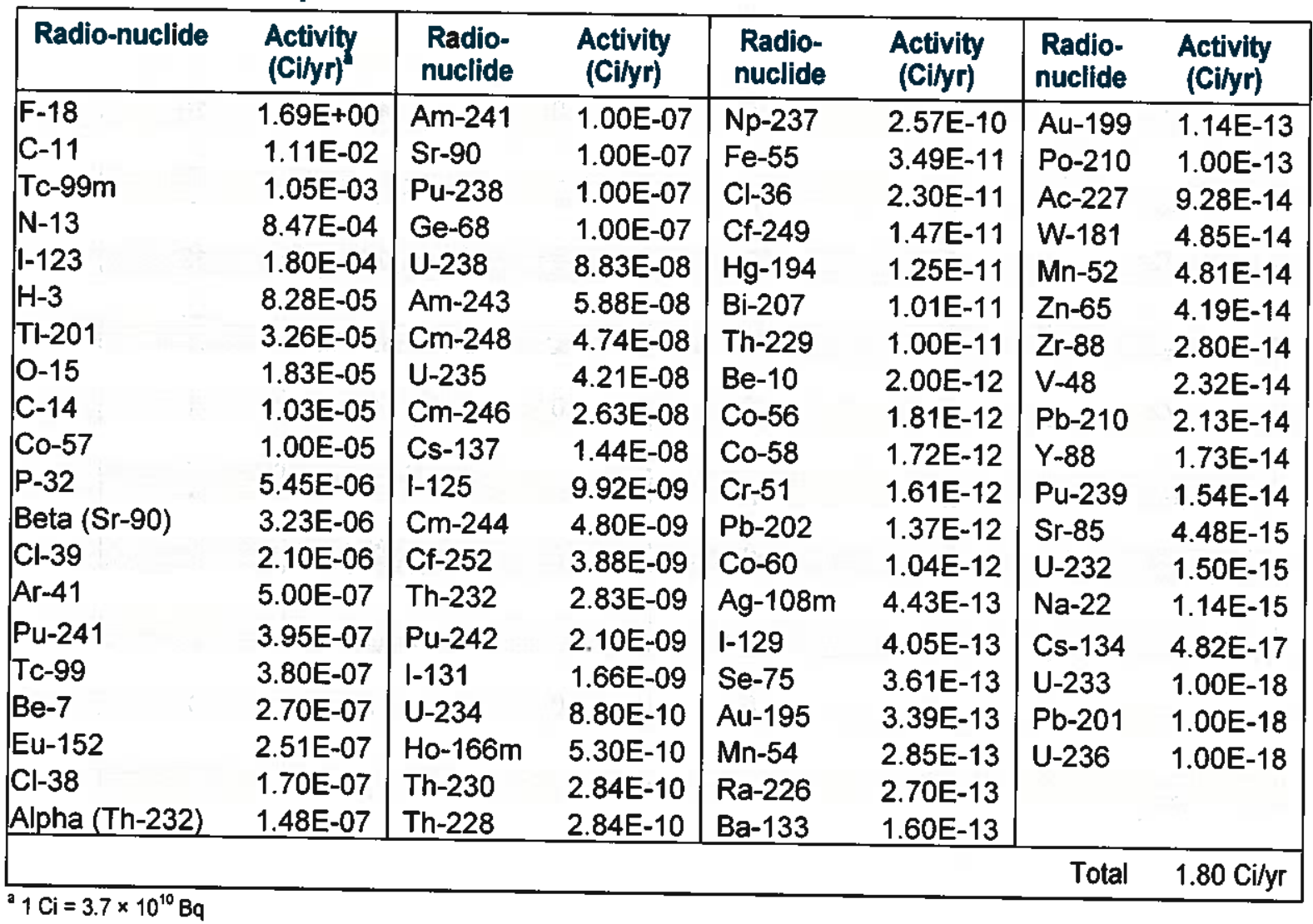


of positron-emitting radionuclides (at Buildings 56 and 88) or alpha-emitting radionuclides (at Building 70A). Real-time measurements are recorded and archived.

Many stacks and vents at Berkeley Lab have effluent controls; that is, a filter to collect particulates or gases before they are released to the atmosphere. For example, the measured stacks (point sources) on Building 88 have high-efficiency particulate air (HEPA) filters to prevent small particles from entering the atmosphere. Where effluent controls are in place, samples are collected downstream from the filter. Table 2-4 details effluent controls on stacks.

\subsection{Group Sources: Calculated Emissions}

In accordance with the EPA-approved approach (Table 2-1), Berkeley Lab calculates emissions from stacks or other exhaust points if the potential dose from the sources is less than 0.01 $\mathrm{mrem} / \mathrm{yr}(0.0001 \mathrm{mSv} / \mathrm{yr})$. These Category 4 sources (typically radioactive material areas where small amounts of radionuclides are authorized for use) are grouped by building, as shown in Table 2-5, to simplify reporting (DOE 1994). The amount of each radionuclide emitted is calculated by multiplying the entire quantity of that radionuclide received, used, or produced during the year by the appropriate EPA-specified release factor based on the radionuclide's physical state (provided in 40 CFR Part 61, Appendix D). This method provides a conservative, upper-bound estimate of the annual emissions.

Emissions are typically calculated assuming that all radionuclides received during the year are used in areas where stacks are not sampled or monitored. In fact, some received radionuclides

Table 2-4 Stacks Where Radionuclide Emissions are Measured

\begin{tabular}{|c|c|c|c|c|c|}
\hline Building & $\begin{array}{l}\text { Number of } \\
\text { Stacks }\end{array}$ & Stack Identification & $\begin{array}{l}\text { Measurement } \\
\text { Category }\end{array}$ & $\begin{array}{c}\text { Emissions } \\
\text { Control }\end{array}$ & $\begin{array}{c}\text { Efficiency } \\
(\%)\end{array}$ \\
\hline 55 & 1 & $55-128 \mathrm{H}$ & 4 & $\begin{array}{c}\text { HEPA }^{a} \\
\text { TEDA-DAC }\end{array}$ & $\begin{array}{l}>99 \\
>75\end{array}$ \\
\hline 56 & 2 & $\begin{array}{c}\text { 56-Accelerator } \\
56 \text {-Glovebox }\end{array}$ & $\begin{array}{l}3 \\
3\end{array}$ & None $^{c}$ & NA \\
\hline 70 & 1 & $70-147 A$ & 4 & HEPA & $>99$ \\
\hline & & 70A-1129P/RT & 3 & HEPA & $>99$ \\
\hline & & $70 \mathrm{~A}-1129 \mathrm{H}$ & 3 & HEPA & $>99$ \\
\hline & 6 & $70 A-2211$ & 4 & None & NA \\
\hline IUA & 6 & $70 \mathrm{~A}-2217$ & 4 & None & NA \\
\hline & & $70 A-2229 A$ & 4 & None & NA \\
\hline & & $70 \mathrm{~A}-2229 \mathrm{~B}$ & 4 & None & NA \\
\hline 75 & 1 & $75-127 \mathrm{H}$ & 3 & HEPA & $>99$ \\
\hline 85 & 2 & $\begin{array}{l}\text { 85-Fumehood } \\
\text { 85-Glovebox }\end{array}$ & $\begin{array}{l}3 \\
3\end{array}$ & HEPA & $>99$ \\
\hline & & $88-135 \mathrm{H}$ & 3 & & \\
\hline 88 & 3 & 88-Cave0 & 3 & HEPA & $>99$ \\
\hline & & 88-RT & 3 & & \\
\hline
\end{tabular}

"High-efficiency particulate air filter

Triethylene-diamine-doped activated carbon trap

${ }^{\dagger}$ Radionuclides emitted from accelerators are short-lived, gaseous, activation products, for which emission control is impractical 
Table 2-5 Sources for Which Radionuclide Emissions are Calculated

\begin{tabular}{|c|c|c|c|}
\hline Building & $\begin{array}{c}\text { Number of Radioactive } \\
\text { Material Areas }\end{array}$ & Emissions Control & $\begin{array}{c}\text { Efficiency } \\
(\%)\end{array}$ \\
\hline 1 & 5 & None & $N A^{a}$ \\
\hline 5 & 1 & None & NA \\
\hline 6 & 2 & None & NA \\
\hline 16 & $2 x-1$ & None & NA \\
\hline 50 & 2 & None & NA \\
\hline 51 & 1 (diffuse) & None & NA \\
\hline 55 & 10 & $\begin{array}{l}\text { HEPA }{ }^{b} \\
\text { None }\end{array}$ & $\begin{array}{l}>99 \\
\text { NA }\end{array}$ \\
\hline 64 & 1 & None & NA \\
\hline 70 & 12 & $\begin{array}{l}\text { HEPA } \\
\text { None }\end{array}$ & $\begin{array}{l}>99 \\
\text { NA }\end{array}$ \\
\hline $70 A$ & 24 & $\begin{array}{l}\text { HEPA } \\
\text { None }\end{array}$ & $\begin{array}{l}>99 \\
\text { NA }\end{array}$ \\
\hline 71 & 1 & None & NA \\
\hline 72 & 1 & None & NA \\
\hline 75 & 3 & $\begin{array}{l}\text { HEPA } \\
\text { None }\end{array}$ & $\begin{array}{l}>99 \\
\text { NA }\end{array}$ \\
\hline $77 \mathrm{~A}$ & 1 & None & NA \\
\hline 83 & 2 & None & NA \\
\hline 84 & 4 & None & NA \\
\hline 86 & 1 & None & NA \\
\hline 88 & 1 & HEPA & $>99$ \\
\hline 977 & 4 & None & NA \\
\hline 978 & 3 & None & NA \\
\hline
\end{tabular}

"Not applicable

${ }^{\mathrm{B}} \mathrm{High}$-efficiency particulate air filter

may be emitted through sampled or monitored stacks and are overestimated because they are accounted for as both calculated and measured emissions. For group sources there typically are no effluent controls because the emissions from these sources are very low activity.

\subsection{Nonpoint Sources: Diffuse Emissions}

In 2011, Berkeley Lab had one potential minor diffuse source, created during demolition of the former Bevatron, Building 51, which required breaking up concrete that had been part of the Bevatron accelerator structure and moving soil that had been under the accelerator. Although emissions were controlled by spraying water whenever there was visible dust, concrete and soil handling could result in diffuse airborne emissions. Because the concrete and soil came from an accelerator facility, very low levels of radionuclides have been measured in these materials. The possible airborne emissions from these activities were estimated using methods described in the EPA document, Methods for Estimating Fugitive Air Emissions of Radionuclides from Diffuse Sources at DOE Facilities (EPA 2004), with concurrence from EPA Region 9 (Appendix A). 


\subsection{Dose Model}

To comply with NESHAP regulations and DOE guidance, the EPA-approved atmospheric dispersion and radiation dose calculation computer code, CAP88-PC, Versions 2.1 and 3.0, was used to calculate the dose at various distances and from various release points (EPA 2006). For buildings 1, 977, and 978, where the nearest member of the public was much less than $328 \mathrm{ft}(100 \mathrm{~m})$ from the source, the EPAapproved dose model COMPLY was used for that location; CAP88-PC was used for doses at all other distances from the building. Doses to members of the public nearest each building were compared, and the location where the dose was greatest was determined to be the Laboratory MEI.

Dose from emissions from individual Laboratory buildings was calculated. For all buildings on the main site, including Building 1 , these individual doses were then summed. (Although Building 1 is located outside of Berkeley Lab's main perimeter and could be considered a separate facility since it is not on the same contiguous site as other main site buildings [see Figure 1-3], Building 1 is located on the adjacent UC Berkeley campus and is within walking distance of the main Berkeley Lab site.) For Buildings 977 (the Berkeley West Biocenter) and 978 (the Joint BioEnergy Institute), doses were evaluated separately from other Laboratory buildings and from each other. Buildings 977 and 978 are located about 3 mi (5 $\mathrm{km}$ ) west and southwest of the main Laboratory site (see Figure 1-2). Annual radioactive air emissions from these off-site buildings and the associated dose to each nearest member of the public are much less than the highest building emissions and doses at the main Berkeley Lab site.

\subsection{Input Parameters}

Input parameters to CAP88-PC and COMPLY include the emissions discussed in Section 2, and buildingspecific and common parameters discussed below. To estimate dose, CAP88-PC, Version 3, provides a library of 825 radionuclides, which includes data for all of the radionuclides listed in Table 2-3 except ${ }^{248} \mathrm{Cm}$ and ${ }^{252} \mathrm{Cf}$. For these radionuclides, Version 2.1 of CAP88-PC was used. (Note that the combined

dose from ${ }^{248} \mathrm{Cm}$ and ${ }^{252} \mathrm{Cf}$ to the sitewide $\mathrm{MEI}$ is very low-only about $1.8 \%$ of the total dose from all radionuclides.)

In addition, when calculating dose from particulate alpha- and beta-emitting radionuclides, Berkeley Lab assigns gross alpha and gross beta measurements to the high-hazard alpha-emitting radionuclide, ${ }^{232} \mathrm{Th}$, and the high-hazard beta-emitting radionuclide, ${ }^{90} \mathrm{Sr}$, respectively. The use of the high-hazard radionuclides ${ }^{232} \mathrm{Th}$ and ${ }^{90} \mathrm{Sr}$ to represent alpha and beta emissions provides an upper-bound estimate of the dose. 


\subsubsection{Building-Specific Parameters}

For dose assessment, some Berkeley Lab buildings can be combined because they are near each other and similar operations are performed there (DOE 1994). For combined buildings and buildings with many unsampled stacks, average stack height and conservative stack diameter $(0.1 \mathrm{~m})$, exit velocity $(0 \mathrm{~m} / \mathrm{s})$, and receptor distance (from nearest edge of building) values are typically used (Table 3-1). These values overestimate the impact of air emissions on a nearby person and are chosen to ensure that stack emissions are not underestimated.

For Buildings 56 and 85, where some radionuclide emissions can be correlated to specific stacks (such as glovebox or fumehood stacks), the actual stack diameter and exit velocity are used and modeled separately. The input parameters that vary with building are shown in Table 3-1.

For Buildings 50 and 77A, authorized radionuclides are in the form of activated components, which are fixed and not readily dispersed into the air. Because airborne radionuclides are unlikely to be released from these buildings, no releases were modeled.

Table 3-1 Building-Specific Input Parameters

\begin{tabular}{|c|c|c|c|c|c|c|}
\hline Building Number & $\begin{array}{c}\text { Stack } \\
\text { Height } \\
\text { (m) }\end{array}$ & $\begin{array}{c}\text { Stack Diameter } \\
(\mathrm{m})\end{array}$ & $\begin{array}{l}\text { Exit Velocity } \\
(\mathrm{m} / \mathrm{s})\end{array}$ & $\begin{array}{l}\text { Nearest } \\
\text { Member of } \\
\text { Public }\end{array}$ & MEI Location & Farm $_{\text {Location }}^{\text {b }}$ \\
\hline 1 & 18 & 0.1 & 0 & $10 \mathrm{~m}$ ESE & $990 \mathrm{~m}$ ENE & $4200 \mathrm{~m} \mathrm{~N}$ \\
\hline $5 / 6 / 16$ & 9 & 0.1 & 0 & $350 \mathrm{~m}$ NNE & $370 \mathrm{~m}$ NNE & $3200 \mathrm{~m} \mathrm{~N}$ \\
\hline 51 (diffuse) & 0 & $6362 \mathrm{~m}^{2}$ & 0 & $400 \mathrm{~m}$ NNW & $410 \mathrm{~m}$ ENE & $3200 \mathrm{~m} \mathrm{~N}$ \\
\hline \multicolumn{7}{|l|}{$55 / 56 / 64$} \\
\hline $\begin{array}{l}\text { Accelerator stack } \\
\text { Glovebox stack } \\
\text { General stacks }\end{array}$ & $\begin{array}{l}16 \\
16 \\
12\end{array}$ & $\begin{array}{c}0.3 \\
0.46 \\
0.1\end{array}$ & $\begin{array}{c}3.60 \\
2.29 \\
0\end{array}$ & $\begin{array}{l}250 \mathrm{~m} \mathrm{NNW} \\
250 \mathrm{~m} \mathrm{NNW} \\
250 \mathrm{~m} \mathrm{NNW}\end{array}$ & $\begin{array}{l}460 \mathrm{mE} \\
460 \mathrm{mE} \\
460 \mathrm{mE}\end{array}$ & $\begin{array}{l}3200 \mathrm{~m} \mathrm{~N} \\
3200 \mathrm{~m} \mathrm{~N} \\
3200 \mathrm{~m} \mathrm{~N}\end{array}$ \\
\hline $70 / 70 A$ & 16 & 0.1 & 0 & $270 \mathrm{~m}$ WSW & $530 \mathrm{~m}$ ENE & $3200 \mathrm{~m} \mathrm{~N}$ \\
\hline 71 & 13 & 0.1 & 0 & $190 \mathrm{~m}$ NNW & $310 \mathrm{~m}$ ESE & $3200 \mathrm{~m} \mathrm{~N}$ \\
\hline 72 & 3 & 0.1 & 0 & $230 \mathrm{~m} \mathrm{SSW}$ & $500 \mathrm{~m} \mathrm{NW}$ & $3200 \mathrm{~m} \mathrm{~N}$ \\
\hline 75 & 7.4 & 0.35 & 8.54 & $110 \mathrm{~m} \mathrm{NW}$ & $110 \mathrm{~m} \mathrm{NW}$ & $3200 \mathrm{~m} \mathrm{~N}$ \\
\hline $83 / 84 / 86$ & 7 & 0.1 & 0 & $160 \mathrm{~m}$ SSE & $690 \mathrm{~m}$ WNW & $3200 \mathrm{~m} \mathrm{~N}$ \\
\hline \multicolumn{7}{|l|}{85} \\
\hline $\begin{array}{l}\text { Glovebox stack } \\
\text { Fumehood stack } \\
\text { General stacks }\end{array}$ & $\begin{array}{l}16 \\
16 \\
16\end{array}$ & $\begin{array}{c}0.23 \\
0.46 \\
0.1\end{array}$ & $\begin{array}{c}6.63 \\
6.70 \\
0\end{array}$ & $\begin{array}{l}210 \mathrm{~m} \text { SSE } \\
210 \mathrm{~m} \text { SSE } \\
210 \mathrm{~m} \text { SSE }\end{array}$ & $\begin{array}{l}570 \mathrm{~m} \text { WNW } \\
570 \mathrm{~m} \text { WNW } \\
570 \mathrm{~m} \text { WNW }\end{array}$ & $\begin{array}{l}3200 \mathrm{~m} \mathrm{~N} \\
3200 \mathrm{~m} \mathrm{~N} \\
3200 \mathrm{~m} \mathrm{~N}\end{array}$ \\
\hline 88 & 13 & 0.1 & 0 & $110 \mathrm{~mW}$ & $690 \mathrm{~m}$ ENE & $3200 \mathrm{~m} \mathrm{~N}$ \\
\hline 977 & 16 & 0.1 & 0 & $30 \mathrm{~m} \mathrm{~N}$ & $30 \mathrm{~m} \mathrm{~N}$ & $8200 \mathrm{~m} \mathrm{~N}$ \\
\hline 978 & 28 & 0.26 & 0 & $19 \mathrm{mE}$ & $19 \mathrm{mE}$ & $8200 \mathrm{~m} \mathrm{~N}$ \\
\hline
\end{tabular}

$1 \mathrm{~m}=3.281 \mathrm{ft}$

${ }^{b}$ Approximate distance to Wildcat Canyon Regional Preserve where cattle graze 
For Buildings 977 and 978, which are off the main Berkeley Lab site and are shared by LBNL employees and members of the public, the distance to the MEI is the shortest distance from the release point on the building roof to the location of the nearest member of the public in the building (measured along the building surfaces). This is the method required by the COMPLY software (EPA 1989b).

\subsubsection{Common Parameters}

The input parameters that are common among Berkeley Lab sources include meteorological data and agricultural data. Meteorological data were compiled from on-site data for 2011. Berkeley Lab collects this data from a $66-\mathrm{ft}(20-\mathrm{m})$ tower located in the central portion of the Laboratory. Site-specific values for annual precipitation $\left(27.3 \mathrm{in}\right.$. [69.3 cm]), average ambient temperature $\left(53.4{ }^{\circ} \mathrm{F}\left[11.9^{\circ} \mathrm{C}\right]\right)$, and average absolute humidity $\left(7.5 \mathrm{~g} / \mathrm{m}^{3}\right)$ were used. The default value for lid (mixing) height, $3300 \mathrm{ft}(1000$ $\mathrm{m})$, was chosen. The 2011 wind data are provided in Appendix B.

Agricultural data were obtained from the California Department of Food and Agriculture and the urban scenario was chosen (Wahl 2004). The values include the following.

- Vegetables, fraction home-produced: 0.076

- Vegetables, fraction from assessment area: 0.924

- Milk, fraction from assessment area: 1

- Meat, fraction home-produced: 0.008

- Meat, fraction from assessment area: 0.992

- Beef cattle density: 1.9 per $\mathrm{km}^{2}$

- Milk cattle density: 4.0 per $\mathrm{km}^{2}$

- Land fraction cultivated for vegetable crops: $4.6 \%$

\subsection{Compliance Assessment}

\subsubsection{MEI Dose and Location}

Doses from Berkeley Lab's airborne emissions are well below the $10 \mathrm{mrem} / \mathrm{yr}(0.1 \mathrm{mSv} / \mathrm{yr}) \mathrm{NESHAP}$ dose standard. As shown in Table 3-2, the sum of calculated doses from all sources at Berkeley Lab main site in 2011 was $5.0 \times 10^{-3} \mathrm{mrem} / \mathrm{yr}\left(5.0 \times 10^{-5} \mathrm{mSv} / \mathrm{yr}\right)$ to the MEI. The location of this hypothetical person is the UC Lawrence Hall of Science, about $1500 \mathrm{ft}(460 \mathrm{~m})$ east of Buildings 55 and 56 . The calculated doses from sources at the offsite Buildings 977 and 978 to the nearest member of the public working in the same building (the building-specific MEI) were much less: $2.4 \times 10^{-4} \mathrm{mrem} / \mathrm{yr}\left(2.4 \times 10^{-6}\right.$ $\mathrm{mSv} / \mathrm{yr})$ and $4.6 \times 10^{-5} \mathrm{mrem} / \mathrm{yr}\left(4.6 \times 10^{-7} \mathrm{mSv} / \mathrm{yr}\right)$, respectively.

Although no one actually lives at the MEI locations, the EPA-approved software calculates the dose assuming a person resides there 24 hours a day for the entire year, eats meat and vegetables grown nearby (see the agricultural parameters in Section 3.2.2), and drinks water from local wells contaminated with deposited airborne radionuclides. Thus the calculated dose to this hypothetical person, the MEI, is greater 
Table 3-2 Dose Assessment Results

\begin{tabular}{|cccc|}
\hline Building & $\begin{array}{c}\text { Primary Radionuclides Contributing to } \\
\text { MEI Dose }\end{array}$ & $\begin{array}{c}\text { Dose to MEI } \\
(\text { mrem/yr) }\end{array}$ & $\begin{array}{c}\text { Percent of Total } \\
\text { Dose (\%) }\end{array}$ \\
\hline 1 & None & $2.8 \mathrm{E}-9$ & $<0.1$ \\
$5 / 6 / 16$ & None & $5.6 \mathrm{E}-7$ & $<0.1$ \\
50 & None & 0 & $<0.1$ \\
51 (diffuse) & None & $2.6 \mathrm{E}-6$ & $<0.1$ \\
$55 / 56 / 64$ & F-18, l-123 & $4.2 \mathrm{E}-3$ & 84.5 \\
$70 / 70 \mathrm{~A}$ & Cm-248, Pu-241, Sr-90 & $6.2 \mathrm{E}-4$ & 12.4 \\
71 & None & $8.3 \mathrm{E}-8$ & $<0.1$ \\
72 & None & 0 & $<0.1$ \\
75 & None & $8.5 \mathrm{E}-6$ & 0.2 \\
$83 / 84 / 86$ & None & $5.5 \mathrm{E}-7$ & $<0.1$ \\
85 & None & $4.2 \mathrm{E}-8$ & $<0.1$ \\
\hline 88 & None & $1.4 \mathrm{E}-4$ & 2.8 \\
Total (Main Site) & & $5.0 \mathrm{E}-3$ & 100 \\
\hline 977 & P-32 & $2.4 \mathrm{E}-4$ & 100 \\
\hline 978 & P-32, H-3 & $4.6 \mathrm{E}-5$ & 100 \\
\hline
\end{tabular}

Radionuclides that contribute more than $1 \%$ of the potential dose to the MEl from this source

${ }^{b}$ Dose from all radionuclides emitted; 1 mrem $=0.01 \mathrm{mSv}$

than the dose to an actual member of the public visiting the Hall of Science or working in Buildings 977 or 978 .

Fluorine-18 emitted from Building 56 stacks accounts for about $80 \%$ of the dose to the Berkeley Lab main site MEI. Approximately $5 \%$ of the dose is due to ${ }^{123} \mathrm{I}$ and its decay products used in Building 55 laboratories.

Annual ${ }^{18} \mathrm{~F}$ emissions from Building 56 stacks are overestimated because false-positive results occur when ${ }^{18} \mathrm{~F}$ adsorbs onto the real-time detectors. These false positive measurements are included in the calculation of annual ${ }^{18} \mathrm{~F}$ emissions. As a result, the calculated dose represents an upper-bound estimate of dose from ${ }^{18} \mathrm{~F}$. Even with this overestimation, the dose to the MEI from ${ }^{18} \mathrm{~F}$ is very low, only about $0.04 \%$ of the EPA limit of $10 \mathrm{mrem} / \mathrm{yr}(0.1 \mathrm{mSv} / \mathrm{yr})$.

The CAP88-PC and COMPLY codes were validated by performing sample assessments. The output of each sample assessment was compared to output provided in the users' guides (EPA 2007, EPA 1989b). The two outputs are identical, indicating that the code performed as intended. 


\subsubsection{Certification}

I certify under penalty of law that I have personally examined and am familiar with the information submitted herein, and based on my inquiry of those individuals immediately responsible for obtaining the information, I believe that the submitted information is true, accurate, and complete. I am aware that there are significant penalties for submitting false information, including the possibility of fine and imprisonment (see 18 U.S.C. 1001).

Certified By:

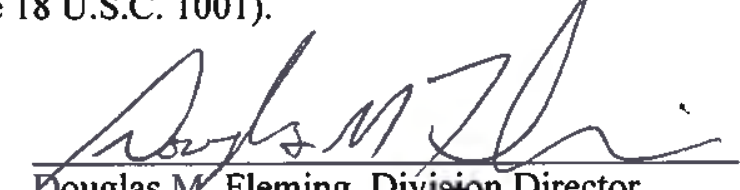

bouglas M. Fleming, Division Director Environment, Health and Safety Division Lawrence Berkełey Nacional Lab

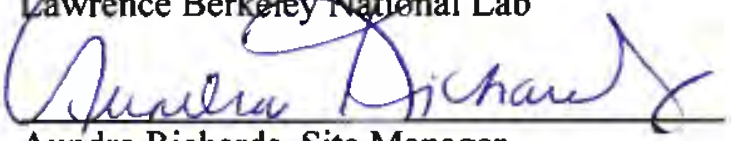

Aundra Richards, Site Manager

Department of Energy

Lawrence Berkeley Site Office
Date:

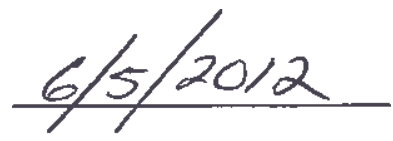

Date:

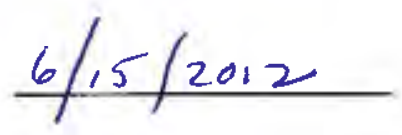




$\frac{4.0}{\text { Additional Information }}$

\subsection{Additions or Modifications}

There was no facility construction or modification (fabrication, erection, or installation) in 2011 relevant to the NESHAP regulation. Other changes in work authorized noted in this report include

- soil handling at the site of Building 51 (the old Bevatron) in preparation for transportation;

- authorization of work with radionuclides in Buildings 64 and 86; and

- cessation of work with radionuclides in Building 26.

\subsection{Unplanned Releases}

There were no unplanned releases in 2011 from Berkeley Lab operations.

\subsection{Diffuse Emissions}

In 2011, Berkeley Lab had one potential minor diffuse source, created during demolition of the former Bevatron, Building 51, which required breaking up concrete that had been part of the Bevatron accelerator structure and moving soil that had been under the accelerator. Although emissions were controlled by spraying water whenever there was visible dust, concrete and soil handling could result in diffuse airborne emissions. Because the concrete and soil came from an accelerator facility, very low levels of radionuclides have been measured in these materials. The possible airborne emissions from these activities were estimated using methods described in the EPA document, Methods for Estimating Fugitive Air Emissions of Radionuclides from Diffuse Sources at DOE Facilities (EPA 2004), with concurrence from EPA Region 9 (Appendix A). The calculated dose from this diffuse source was very low, $2.6 \times 10^{-6}$ $\mathrm{mrem} / \mathrm{y}$, which is less than $0.1 \%$ of the total dose to the Laboratory main site MEI. 


\subsection{Collective Dose Estimate}

Collective population dose is calculated as the average radiation dose to a person in a specified area, multiplied by the number of people in that area. In accordance with DOE and EPA guidance documents, all radionuclides potentially emitted from the main Laboratory site in 2011 (shown in Table 2-3) were assumed to be released from a hypothetical, centrally located stack that is $52 \mathrm{ft}$ (16 m) high, is $1 \mathrm{ft}(0.3 \mathrm{~m})$ in diameter, and has an exit velocity of $13.5 \mathrm{ft} / \mathrm{s}(4.1 \mathrm{~m} / \mathrm{s}$ ) (Wahl 2003). Radionuclides potentially emitted from Building 977 were assumed to be released from the building stack, which is $52 \mathrm{ft}(16 \mathrm{~m})$ high, is conservatively assumed to be $0.3 \mathrm{ft}(0.1 \mathrm{~m})$ in diameter, and has a conservatively assumed exit velocity of $0 \mathrm{ft} / \mathrm{s}(0 \mathrm{~m} / \mathrm{s})$. Radionuclides potentially emitted from Building 978 were assumed to be released from the building stack, which is $92 \mathrm{ft}(28 \mathrm{~m})$ high, is $0.85 \mathrm{ft}(0.26 \mathrm{~m})$ in diameter, and has a conservatively assumed exit velocity of $0 \mathrm{ft} / \mathrm{s}(0 \mathrm{~m} / \mathrm{s})$.

The total population within $50 \mathrm{mi}(80 \mathrm{~km})$ of the main Laboratory site is approximately $6,615,000$ based on the LandScan Global Population Database (Dobson and Bright 2002; Gallegos 2002). The same population was assumed to be appropriate for Buildings 977 and 978 , since they are relatively close to (within $3 \mathrm{mi}[5 \mathrm{~km}]$ of) the main Laboratory site. The population file is provided in Appendix C. The estimated collective dose to persons living within $50 \mathrm{mi}(80 \mathrm{~km})$ of the main Berkeley Lab site is $1.1 \times$ $10^{-1}$ person-rem $\left(1.1 \times 10^{-3}\right.$ person-Sv) attributable to Berkeley Lab airborne emissions in 2011 . The collective doses from Building 977 and 978 are $9.5 \times 10^{-6}$ person-rem $\left(9.5 \times 10^{-8}\right.$ person-Sv) and $1.7 \times 10^{-7}$ person-rem $\left(1.7 \times 10^{-9}\right.$ person-Sv), respectively.

\subsection{CFR 61 Subparts $Q$ and T}

Subparts Q and T of 40 CFR 61 are not applicable to Berkeley Lab, as the Laboratory does not operate a storage and disposal facility for radium-containing material or uranium mill tailings.

\subsection{Radon Emissions}

The Laboratory does not process, manage, or possess ${ }^{232} \mathrm{U}$ or ${ }^{232} \mathrm{Th}$ in quantities that could produce ${ }^{220} \mathrm{Rn}$ emissions having an impact $\geq 0.1 \mathrm{mrem} / \mathrm{yr}(0.001 \mathrm{mSv} / \mathrm{yr})$ or $\geq 10 \%$ of the nonradon dose to the public. The Laboratory does not maintain nondisposal or nonstorage sources of ${ }^{222} \mathrm{Rn}$ emissions in quantities having an impact $\geq 0.1 \mathrm{mrem} / \mathrm{yr}(0.001 \mathrm{mSv} / \mathrm{yr})$ or $\geq 10 \%$ of the nonradon dose to the public.

\subsection{Facility Compliance}

In 2011, no release points produced emissions having an impact $\geq 0.1 \mathrm{mrem} / \mathrm{yr}(0.001 \mathrm{mSv} / \mathrm{yr})$ and no sources were subject to continuous monitoring requirements. Periodic confirmatory measurements were conducted in accordance with the EPA-approved measurement approach (Table 2-1). 
DOE 1994: U.S. Department of Energy, "Calendar Year 1993 Radionuclide Air Emissions Annual Reports for DOE Sites," memo to DOE site offices providing guidance for report preparation (March 22, 1994).

Dobson and Bright 2002: Dobson, J. E., and E. A. Bright, Landscan Global Population 1998 Database, www.ornl.gov/gist/projects/LandScan/landscan_doc.htm (August 2002).

EPA 1989a: U.S. Environmental Protection Agency, National Emission Standards for Emissions of Radionuclides Other Than Radon From Department of Energy Facilities, 40 CFR Part 61, Subpart H (1989, as amended).

EPA 1989b: U.S. Environmental Protection Agency, Users Guide for the COMPLY Code, EPA 520/189/2003 (October 1989).

EPA 2004: US Environmental Protection Agency, Methods for Estimating Fugitive Air Emissions of Radionuclides from Diffuse Sources at DOE Facilities, Final Report, Eastern Research Group, Inc. (September 3, 2004).

EPA 2006: U.S. Environmental Protection Agency, National Emission Standards for Hazardous Air Pollutants (Radionuclides), Availability of Updated Compliance Model, Federal Register, Vol. 71, No. 34, p. 8854 (February 21, 2006).

EPA 2007: U.S. Environmental Protection Agency, CAP88-PC Version 3.0 User Guide, Trinity Engineering Associates, Inc. (December 2007).

Gallegos 2002: Gallegos, G., "Estimating Populations for Collective Dose Calculations," Health Physics, Volume 83, Number 2, pages 283-286 (August 2002).

Jordan 2005: Jordan, D., "Request for Approval for LBNL to Revise Its Radionuclide NESHAP Monitoring Approach," memo from EPA Region 9 to R. Pauer, LBNL, documenting approval of monitoring approach (April 5, 2005).

MTC/ABAG 2010: Metropolitan Transportation Commission/Association of Bay Area Governments, Bay Area Census, 2010 census data website, http://www.bayareacensus.ca.gov/cities/cities.htm (accessed April 3, 2012).

Wahl 2003: Wahl, L., "Annual Calculation of Collective Dose from Airborne Radionuclides," memo ES03-037 to file documenting stack parameters for collective dose calculations (October 9, 2003).

Wahl 2004: Wahl, L., "Agricultural Data Used in CAP88-PC," memo ES-05-003 to file documenting source of agricultural values used for collective dose calculations (October 26, 2004). 


\section{Letter Requesting EPA Concurrence with Bevatron Diffuse Source Approach}

From: Rosenblum.Shelly@epamail.epa.gov <Rosenblum.Shelly@epamail.epa.gov>

Fri, Apr 15, 2011 at

To: lewahl@lbl.gov

Dear Ms. Wahl:

Thank you for informing me of this action. I concur with the use of the attached method for analyzing the emissions from the removal of concrete from the demolition of the Bevatron Acclerator site.

sincerely,

Shelly Rosenblum

-----Linnea Wahl <lewahl@|bl.gov> wrote: -----

To: Shelly Rosenblum/R9/USEPA/US@EPA

From: Linnea Wahl < lewahl@|bl.gov>

Date: 04/15/2011 06:05PM

Cc: "Abbott, Kim" <Kim.Abbott@bso.science.doe.gov>, Ronald Pauer $<$ ropauer@lbl.gov>, Douglas Fleming <dmfleming@lbl.gov>, Suzie Kim

<suziehkim@lbl.gov>

Subject: Letter Requesting EPA Concurrence with Bevatron Diffuse Source Approach [Quoted text hidden]

[attachment "EPADilfuseSourceRequest.pdf" removed by Shelly

Rosenblum/R9/USEPA/US]

\section{EPADiifuseSourceRequest.pdf \\ $255 \mathrm{~K}$}




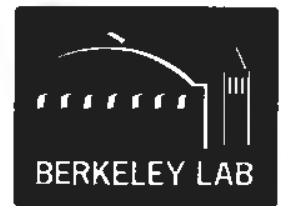

Environmental Services Group

Environment, Health \& Safety Division

ES-11-056

April 15, 2011

Mr. Shelly Rosenblum

U.S. Environmental Protection Agency, Region 9

75 Hawthorne Street

San Francisco, CA, 94105

Dear Mr. Rosenblum,

In 2010, Lawrence Berkeley National Laboratory (LBNL) conducted demolition activities at the site of the former Bevatron, Building 51, which included breaking up concrete that had been part of the Bevatron accelerator structure. Although emissions were controlled by spraying water whenever there was visible dust, concrete rubbling could result in diffuse airborne emissions. Because the concrete came from an accelerator facility, very low levels of radionuclides have been measured in some of the concrete.

To account for dose to the public from these diffuse airborne emissions, we propose first to conservatively estimate the source term (in curies/year) by multiplying the maximum activity of each radionuclide $\left({ }^{60} \mathrm{Co},{ }^{152} \mathrm{Eu}\right.$, and $\left.{ }^{3} \mathrm{H}\right)$ measured in the concrete, the total quantity of concrete broken up or shipped during the year, and the Environmental Protection Agency's (EPA's) air pollutant emission factor. Use of the EPA's emission factor is recommended in "Methods for Estimating Fugitive Air Emissions of Radionuclides from Diffuse Sources at DOE Facilities." Table ES-1 in this document recommends using the "AP-42 aggregate handling emission factor" for diffuse source emissions from demolition activities. The appropriate AP-42 emission factor for concrete rubbling with dust suppression is 0.0006 kilograms of total particulate matter per megagram of concrete processed (controlled tertiary crushing). ${ }^{2}$

Using the calculated source term, we will then model the dose to the maximally exposed individual as a ground-level area source using the EPA-approved CAP88-PC dose calculation software. Other model input will include on-site meteorological data from the reporting year (as is used for all LBNL sources of airborne radionuclides). 
Preliminary dose estimates indicate that using this approach, the dose to the maximally exposed individual will be inconsequential: on the order of 1 nanorem/year. This will not significantly affect the total dose to the maximally exposed individual from Berkeley Lab operations, which was 0.007 millirem/year in 2009.

The EPA document describing methods for estimating fugitive air emissions indicates that LBNL should provide its methodology for assessing diffuse sources to EPA Region 9 for review (p. xiii). ${ }^{1}$ This memo documents LBNL's submission to EPA for review.

Do you concur with this approach to determining diffuse airborne emissions from demolition operations at the site of the former Bevatron? If so, this is the method we will use in reporting the 2010 and future years' annual radionuclide air emissions from the Building 51 Bevatron demolition under the National Emissions Standards for Hazardous Air Pollutants (NESHAP).

We look forward to your response, if at all possible, by May 1. Please do not hesitate to contact me (510-486-7614) or Linnea Wahl (510-486-7623) if you have any questions.

Sincerely,



for

Ron Pauer

LBNL Environmental Services Group Leader

\section{References}

1. U.S. Environmental Protection Agency, "Methods for Estimating Fugitive Air Emissions of Radionuclides from Diffuse Sources at DOE Facilities," September 3, 2004 (http://www.epa.gov/radiation/neshaps/pubs.html, accessed 4/14/11).

2. U.S. Environmental Protection Agency, "Compilation of Air Pollutant Emission Factors, Volume I, Stationary Point and Area Sources," AP-42, $5^{\text {th }}$ edition, January 1995 (http://www.epa.gov/ttnchiel/ap42/, accessed 4/14/11).

Cc: $\quad$ Kim Abbott, DOE Berkeley Site Office

Doug Fleming, LBNL Environment, Health, and Safety Division

Linnea Wahl, LBNL Environmental Services Group

ESG files 


\title{
Linnea Wahl<lewahl@lbl.gov> Letter Requesting EPA Concurrence with 2011 Bevatron Diffuse Source Approach
}

Shelly Rosenblum <Rosenblum.Shelly@epamail.epa.gov>

Mon, Mar 19, 2012 at 9:20 AM

To: Linnea Wahl<lewahl@lbl.gov>

I concur with the attached methodology.

\author{
Shelly Rosenblum \\ Radiation \& Indoor Environments Teams \\ EPA / AIR-6 \\ 75 Hawthorne St \\ San Francisco, CA 94105 \\ 415-947-4193 fax: 3583 \\ rosenblum.shelly@epa.gov
}

The indoor environment is as fascinating and complex as the outdoor environment, but we spend $90 \%$ of our day indoors. The indoor environment is the human environment. Learn how to protect it at our website: http://www.epa.gov/iag.

From: Linnea Wahl <lewahl@elbl.gov>

To: Shelly Rosenblum/R9/USEPAUS@EPA

Date: $\quad 03 / 14 / 201211: 20 \mathrm{AM}$

Subject: Letter Requesting EPA Concurrence with 2011 Bevatron Diffuse Source Approach

Hi Shelly,

As we discussed, I have attached a letter requesting your concurrence with our proposed approach to calculating emissions from soil handled at the Bevatron in 2011. A hard copy of this letter is in the mail to you.

Please reply at your convenience; email or hard copy, either is fine. FYI, I provided below your response to last year's request regarding our concrete handling operations at the Bevatron.

Many thanks.

Linnea 


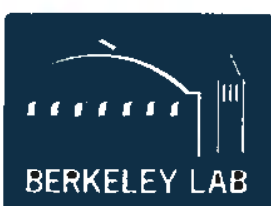

Environmental Services Group

Environment, Health \& Safety Division

ES-12-060

March 14, 2012

Mr. Shelly Rosenblum

\section{U.S. Environmental Protection Agency, Region 9}

75 Hawthorne Street

San Francisco, CA, 94105

Dear Mr. Rosenblum,

In 2011, Lawrence Berkeley National Laboratory (LBNL) conducted demolition activities at the site of the former Bevatron, Building 51, which included handling and removing soil that had been beneath the Bevatron accelerator. As expected, very low levels of radionuclides were measured in some of the soil. Although emissions from soil handling operations were controlled by spraying water whenever there was visible dust, these operations could have resulted in diffuse airborne emissions.

To account for dose to the public from such diffuse airborne emissions, we propose first to conservatively estimate the source term $\left({ }^{152} \mathrm{Eu}\right.$ and ${ }^{3} \mathrm{H}$ in curies per year) using the "Preferred Method to Estimate Radionuclide Emissions from Ongoing Waste Pile Operations and Soil Removal," equation 7-5, from the Environmental Protection Agency's (EPA's) "Methods for Estimating Fugitive Air Emissions of Radionuclides from Diffuse Sources at DOE Facilities." This method takes into account particle size, wind speed, moisture content of the soil, and quantity of soil handled. Where site-specific values are not available, the most conservative default value will be used.

Using the calculated source term, we will then model the dose to the maximally exposed individual as a ground-level area source using the EPA-approved CAP88-PC dose calculation software. Other model input will include on-site meteorological data from the reporting year (as is used for all LBNL sources of airborne radionuclides).

Preliminary dose estimates indicate that using this approach, the dose to the maximally exposed individual will be inconsequential: on the order of picorems per year. This will not significantly affect the total dose to the maximally exposed individual from Berkeley Lab operations, which was $0.007 \mathrm{millirem} / \mathrm{year}$ in 2010 . 
The EPA document describing methods for estimating fugitive air emissions indicates that LBNL should provide its methodology for assessing diffuse sources to EPA Region 9 for review (p. xiii).' This memo documents LBNL's submission to EPA for review.

Do you concur with this approach to determining diffuse airborne emissions from demolition operations at the site of the former Bevatron? If so, this is the method we will use in reporting the 2011 and future years' annual radionuclide air emissions from similar soil handling operations under the National Emissions Standards for Hazardous Air Pollutants (NESHAP).

We look forward to your response, if at all possible, by May 1. Please do not hesitate to contact me (510-486-7614) or Linnea Wahl (510-486-7623) if you have any questions.

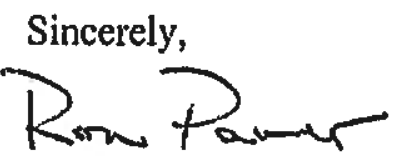

\section{Ron Paller}

LBNL Environmental Services Group Leader

\section{References}

1. U.S. Environmental Protection Agency, "Methods for Estimating Fugitive Air Emissions of Radionuclides from Diffuse Sources at DOE Facilities," September 3, 2004 (http://www.epa.gov/radiation/neshaps/pubs.html, accessed 4/14/11).

Via e-mail

Cc: Kim Abbott, DOE Berkeley Site Office

Doug Fleming, LBNL Environment, Health, and Safety Division

David Kestell, LBNL Environment, Health, and Safety Division

Jack Salazar, LBNL Environment, Health, and Safety Division

Linnea Wahl, LBNL Environmental Services Group

ESG files 


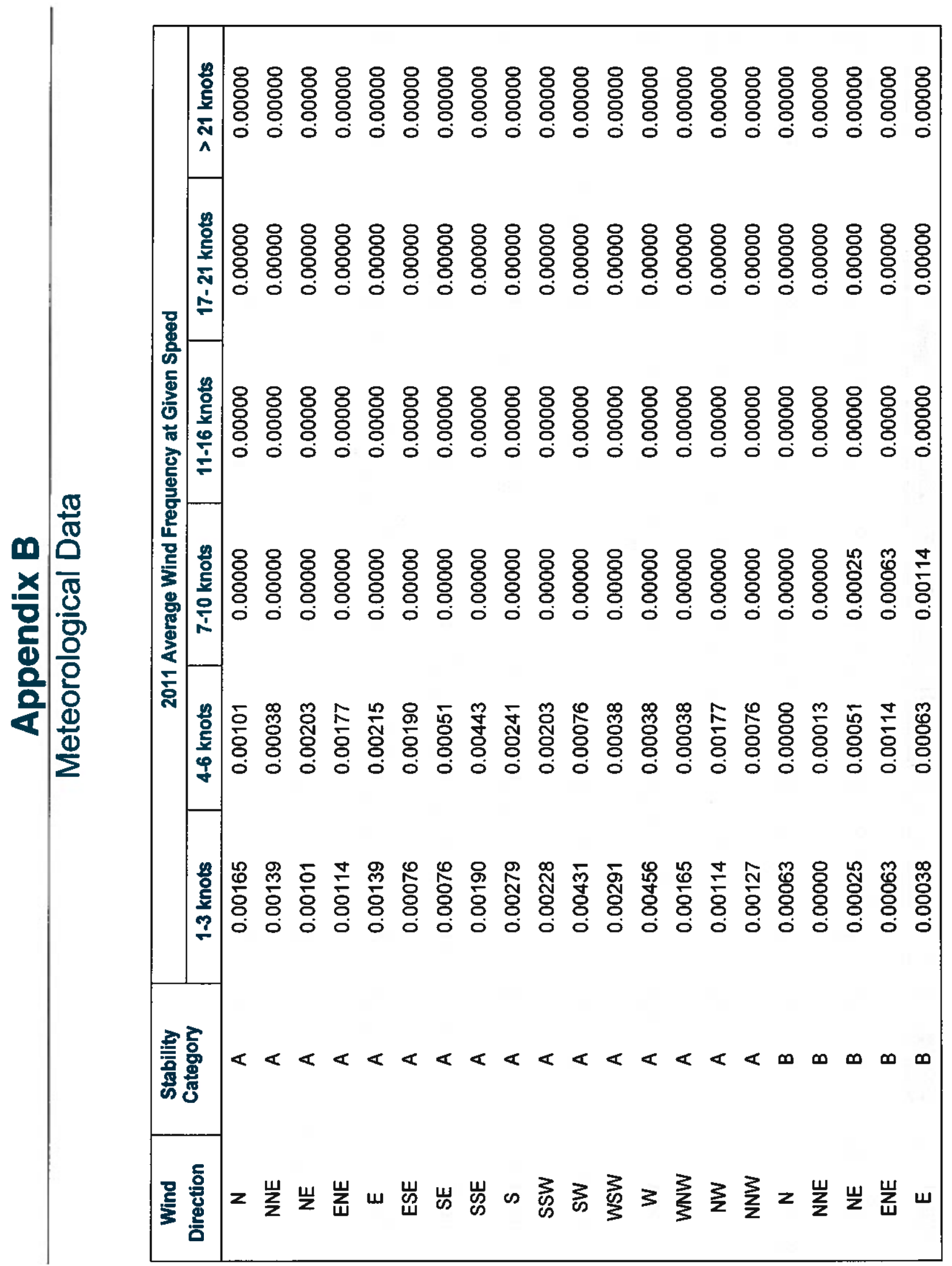




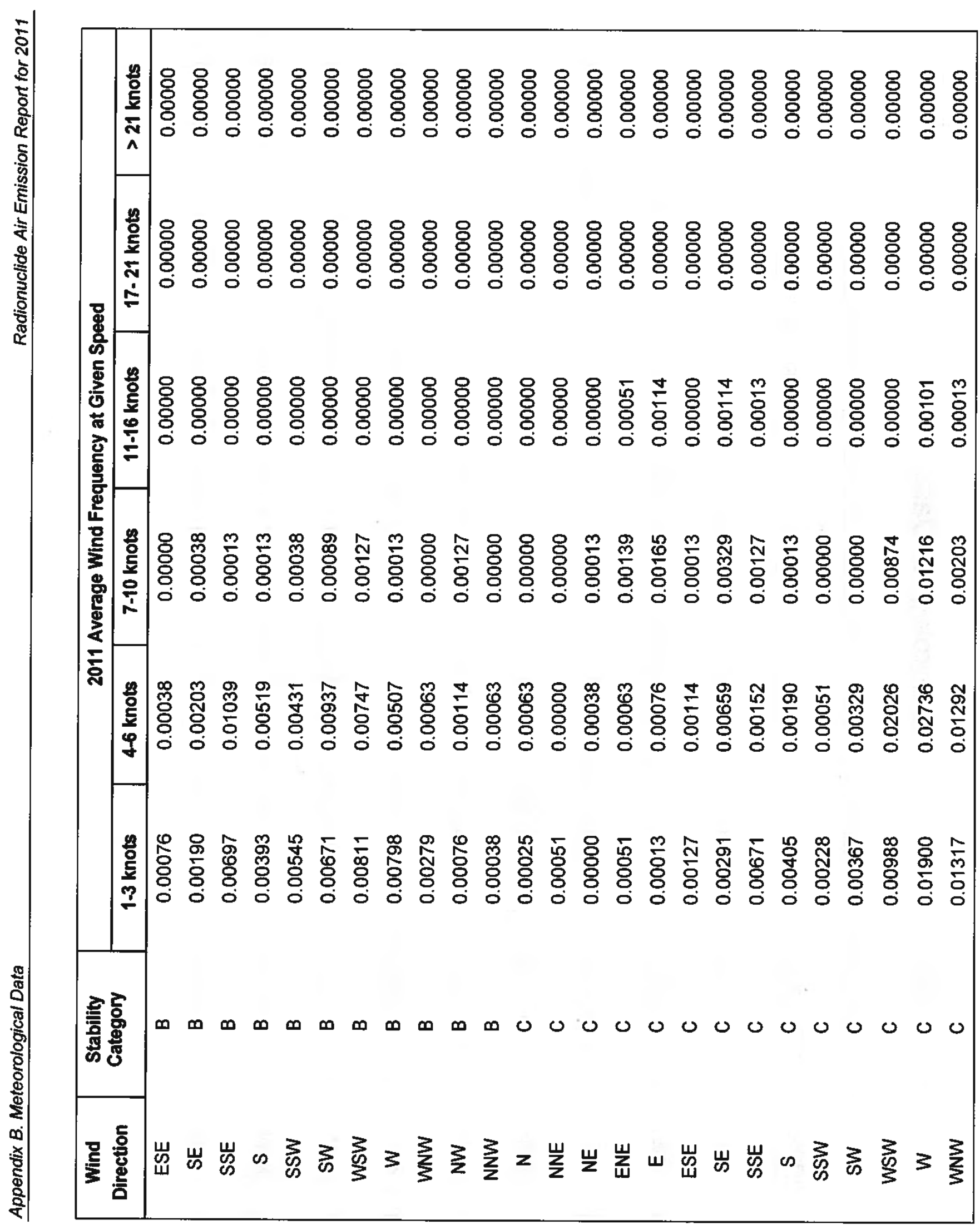









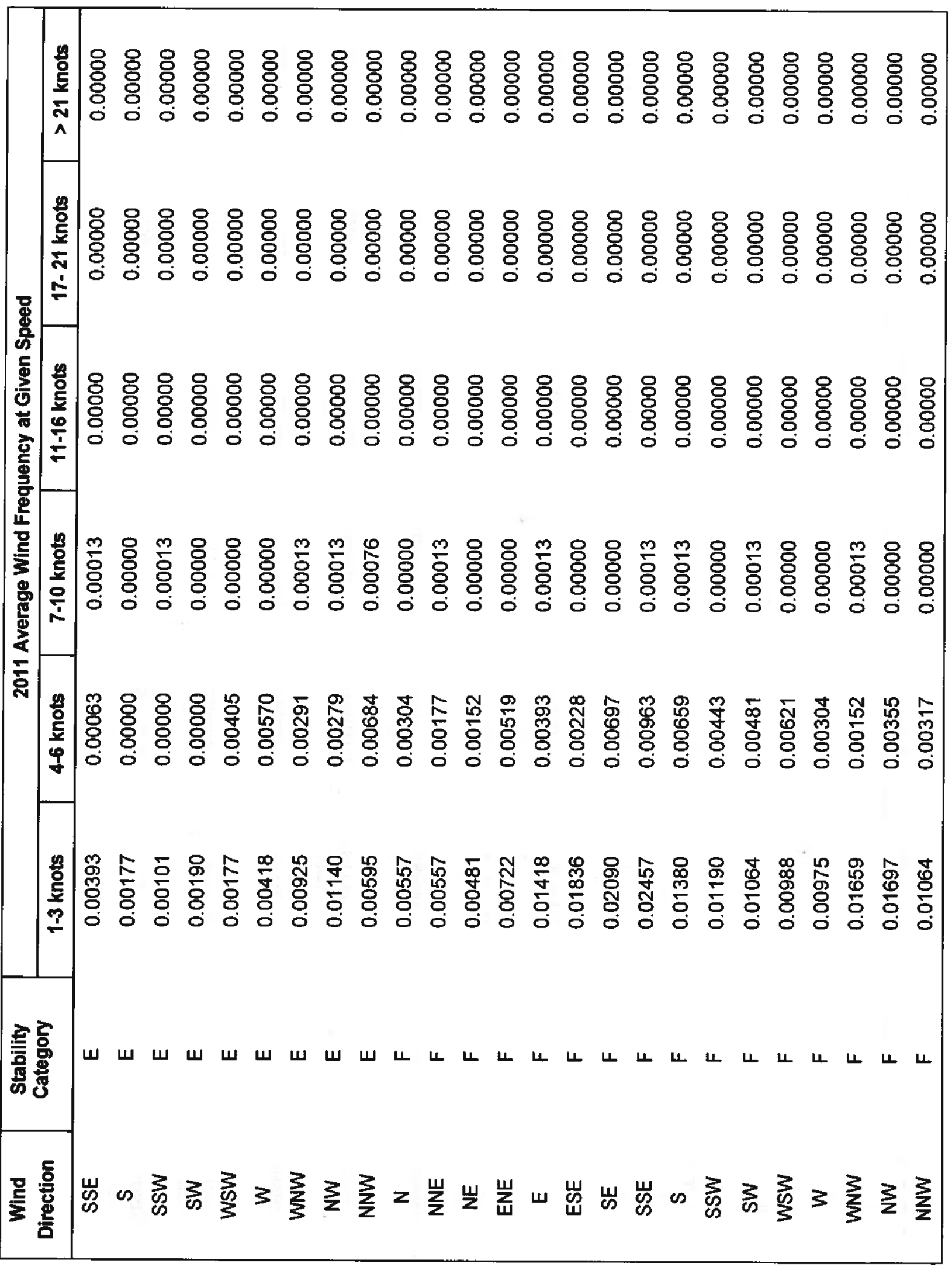




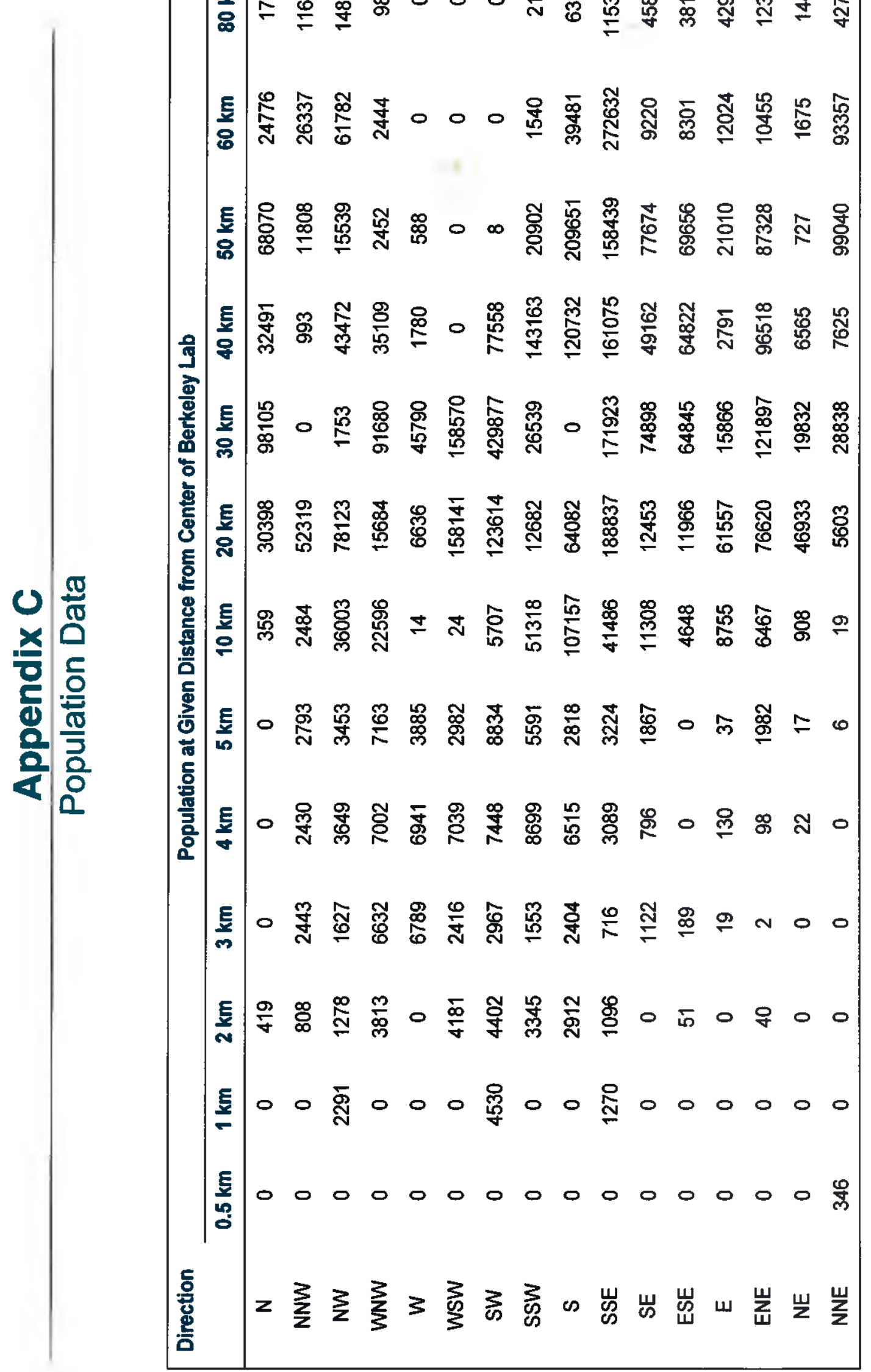




\section{DISCLAIMER}

This document was prepared as an account of work sponsored by the United States Government. While this document is believed to contain correct information, neither the United States Government nor any agency thereof, nor the Regents of the University of California, nor any of their employees, makes any warranty, express or implied, or assumes any legal responsibility for the accuracy, completeness, or usefulness of any information, apparatus, product, or process disclosed, or represents that its use would not infringe privately owned rights. Reference herein to any specific commercial product, process, or service by its trade name, trademark, manufacturer, or otherwise, does not necessarily constitute or imply its endorsement, recommendation, or favoring by the United States Government or any agency thereof, or the Regents of the University of California. The views and opinions of authors expressed herein do not necessarily state or reflect those of the United States Government or any agency thereof or the Regents of the University of California. 